\title{
Supplementary Chapter 1. A brief summary of mechanics-based design for beams and columns.
}

\section{Introduction}

In this supplementary chapter, we sketch the principles of mechanics as applied to building structures. Although the principles illustrated here are quantified, made rational, and used extensively in the non-empirical design of buildings, we are presenting this material to have available a vocabulary for discussing the loads on buildings and the modes of resistance of a building structure.

There are many further references available for students interested in a more extensive exploration into this way of describing building structures. These references fall into the categories of intuitive explanations of they way that structures work, simplified applications of mechanics to the design of structures, and books that use a mechanics-based approach to develop rules for the sizing of structural members

Intuitive explanations of the mechanics of building structures.

Yeomans, David, How Structures Work: Design and Behaviour from Bridges to Buildings, Second Edition. John Wiley and Sons, 2016.

Salvadori, Mario, Why Buildings Stand Up: The Strength of Architecture, W.W. Norton, 2002

Applications of quantitative mechanics to the simplified design of building structures.

Ambrose, James, Simplified Engineering for Architects and Builders, $11^{\text {th }}$ edition, Wiley, 2011

Garrison, Philip, Basic Structures, Wiley/Blackwell, 2011

Inouye, Barry and Kane, Kevin, Statics and Strength of Materials for Architecture and Building

Construction, Fourth Edition, Pearson Prentice Hall, 2012

Mechanics-based approaches to the development of rules for the sizing of structural members

Place, Jeffrey Wayne. Architectural Structures, J. Wiley and Sons, 2007.

Allen, Edward. The Architect's Studio Companion, fourth edition, Wiley, 2007

In the approach presented in the published version of this book, the principles of mechanics are not used explicitly as a way of developing structural designs of buildings. Although the rules that we will use can certainly be connected to quantitative mechanics, it much more fruitful, at an early stage in the development of a building professional, to develop the ability to apply these rules, without recourse to mechanics-based explanations.

\section{Gravity Loads and load paths}

\section{Gravity Loads}

Gravity loads include dead load, live load, and snow load. Dead load is the self-weight of the structure and the weight of objects permanently attached to the building. Live load is the weight of the building occupants and any movable furniture, fixtures, or equipment used in the building. Snow load is the weight of snow on the roof of the building.

\section{Dead Load}

Dead load is calculated by finding the total weight of the fixed components of the building structure. It is expressed in units of force intensity, $\mathrm{lb} / \mathrm{ft}^{2}$ or $\mathrm{N} / \mathrm{m}^{2}$. An allowance for later revisions or additions is often made, as will be shown in the case of roof loading. Many of the components of the building are incorporated by a 
conservative estimate, and the loads are often rounded upwards. For a floor system such as that shown in Figure $\mathrm{S} 1.1$, for instance, it is possible to estimate the weight of the floor component by component.

\section{Figure S1.1. Wood floor framing systems.}
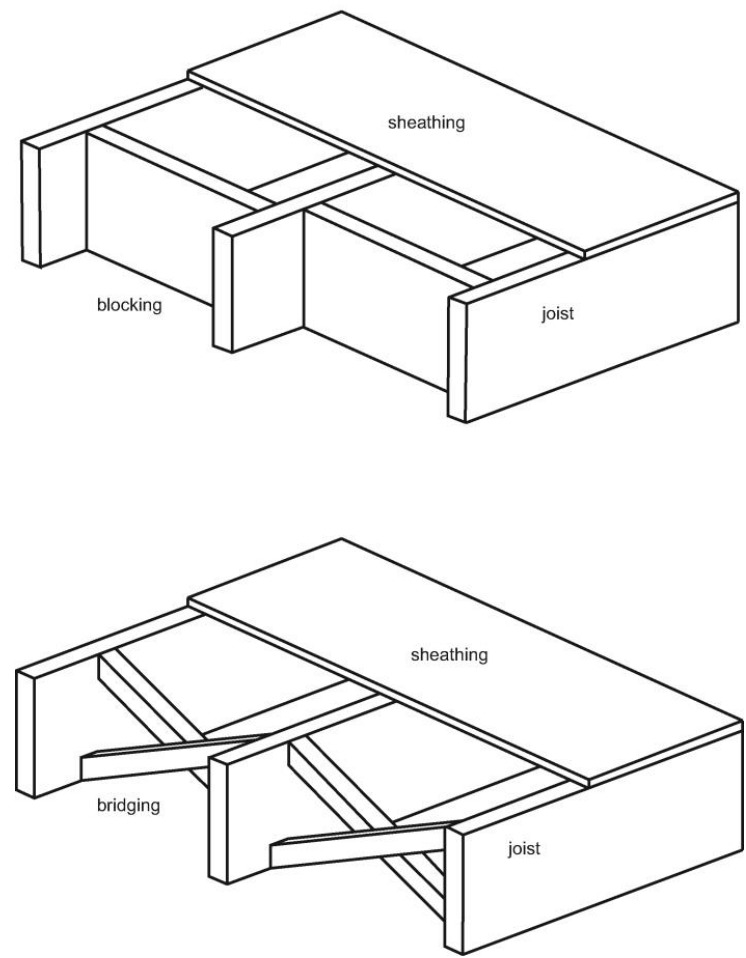

\section{US}

Considering, for instance a residential floor framed with dimension lumber (2 × $10 @ 24$ in.) and plywood (3/4 in.), using a conservative estimate of wood density of $35 \mathrm{lbs} / \mathrm{ft}^{3}$, one can calculate the self-weight of the floor system as

$$
2 \times 10 \text { joists } @ 24 \text { in. } \quad \frac{1.5 \mathrm{in} \times 9.25 \mathrm{in}}{2 \mathrm{ft}} \times 12 \frac{\mathrm{in}}{\mathrm{ft}} \times \frac{35 \mathrm{lbs} / \mathrm{ft}^{3}}{1728 \mathrm{in}^{3} / \mathrm{ft}^{3}}=1.69 \frac{\mathrm{lb}}{\mathrm{ft}^{2}}
$$

In the above calculation, 1.5 in $\times 9.25$ in is the actual size of a $2 \times 10$, the two feet in the denominator of the first fraction represents the 24 inch spacing, and $35 \mathrm{lbs} / \mathrm{ft}^{3}$ is the assumed density of the wood. $3 / 4$ in. plywood $=2.18 \mathrm{lb} / \mathrm{ft}^{2}$

allowance for bridging/blocking $=0.5 \mathrm{lbs} / \mathrm{ft}^{2}$

total self-weight $\approx 4.5 \mathrm{lbs} / \mathrm{ft}^{2}$

To the self-weight is added

flooring $1 \mathrm{lb} / \mathrm{ft}^{2}$

ceiling finish $\quad 1 \mathrm{lb} / \mathrm{ft}^{2}$

mechanical/electrical allowance $\quad 2 \mathrm{lb} / \mathrm{ft}^{2}$

so the total dead load is $8.5 \mathrm{lbs} / \mathrm{ft}^{2}$, which is rounded up to a customary value of $10 \mathrm{lb} / \mathrm{ft}^{2}$. This value of $10 \mathrm{lb} / \mathrm{ft}^{2}$ is used widely for residential floors without some especially heavy component, such as full-depth quarry tile. 


\section{UK}

Using UK standard sizes, the above calculation is

$38 \mathrm{~mm} \times 250 \mathrm{~mm}$ joists @ $600 \mathrm{~mm}$ spacing $\frac{(38 \times 250) \mathrm{mm}^{2}}{600 \mathrm{~mm}} \times 560 \frac{\mathrm{kg}}{\mathrm{m}^{3}}=8.3 \frac{\mathrm{kg}}{\mathrm{m}^{2}}=87 \mathrm{~N} / \mathrm{m}^{2}$

$18 \mathrm{~mm}$ plywood $=100 \mathrm{~N} / \mathrm{m}^{2}$

allowance for bridging/blocking $=25 \mathrm{~N} / \mathrm{m}^{2}$

To the self-weight is added

flooring $50 \mathrm{~N} / \mathrm{m}^{2}$

ceiling finish $50 \mathrm{~N} / \mathrm{m}^{2}$

mechanical/electrical allowance $100 \mathrm{~N} / \mathrm{m}^{2}$

Total floor dead load $\quad 410 \mathrm{~N} / \mathrm{m}^{2}$, say $500 \mathrm{~N} / \mathrm{m}^{2}$

\section{Canada}

Using Canadian standard sizes, the above calculation is

$38 \mathrm{~mm} \times 235 \mathrm{~mm}$ joists @ $600 \mathrm{~mm}$ spacing $\frac{(38 \times 235) \mathrm{mm}^{2}}{600 \mathrm{~mm}} \times 560 \frac{\mathrm{kg}}{\mathrm{m}^{3}}=8.3 \frac{\mathrm{kg}}{\mathrm{m}^{2}}=82 \mathrm{~N} / \mathrm{m}^{2}$

$19 \mathrm{~mm}$ plywood $=100 \mathrm{~N} / \mathrm{m}^{2}$

allowance for bridging/blocking $=25 \mathrm{~N} / \mathrm{m}^{2}$

To the self-weight is added

flooring $50 \mathrm{~N} / \mathrm{m}^{2}$

ceiling finish $50 \mathrm{~N} / \mathrm{m}^{2}$

mechanical/electrical allowance $100 \mathrm{~N} / \mathrm{m}^{2}$

Total floor dead load $\quad 410 \mathrm{~N} / \mathrm{m}^{2}$, say $500 \mathrm{~N} / \mathrm{m}^{2}$

The same calculation for a roof would also include a smaller size rafter and approximately $3 \mathrm{lb} / \mathrm{ft}^{2}\left(150 \mathrm{~N} / \mathrm{m}^{2}\right)$ for the shingles and underlayment, resulting in a total roof load of approximately $10 \mathrm{lb} / \mathrm{ft}^{2}\left(500 \mathrm{~N} / \mathrm{m}^{2}\right)$.

However, in roof replacements, the new shingles are often placed without removing the old shingles - in allowing for this contingency, a customary residential roof dead load of $15 \mathrm{lb} / \mathrm{ft}^{2}\left(75 \mathrm{~N} / \mathrm{m}^{2}\right)$ is widely used.

Since the design of the framing for a building depends on the dead load, it is impossible to find the structure self-weight exactly before the structure has actually been designed. To resolve this paradox, empirically determined allowances are often substituted for the calculation of some parts of the structure self-weight.

\section{US}

Examples of such allowances are

Roof dead load: residential, including finish

$15 \mathrm{lbs} / \mathrm{ft}^{2}$

Floor dead load: residential, including finish

$10 \mathrm{lbs} / \mathrm{ft}^{2}$

Weight of steel framing, commercial/industrial roof

$10 \mathrm{lbs} / \mathrm{ft}^{2}$

Weight of steel framing, office floor

$10 \mathrm{lbs} / \mathrm{ft}^{2}$

Weight of steel framing, institutional floor

$15 \mathrm{lbs} / \mathrm{ft}^{2}$

Reinforced concrete beam/girder/slab floor system, office

$80 \mathrm{lbs} / \mathrm{ft}^{2}$ 
The non-structure dead load may also be specified by an allowance, called the superimposed dead load. Values of superimposed dead load used in commercial/institutional construction range between 15-25 $\mathrm{lb} / \mathrm{ft}^{2}$.

\section{UK}

Examples of such allowances are

Roof dead load: residential, including finish

$750 \mathrm{~N} / \mathrm{m}^{2}$

Floor dead load: residential, including finish

$500 \mathrm{~N} / \mathrm{m}^{2}$

Weight of steel framing, commercial/industrial roof

$500 \mathrm{~N} / \mathrm{m}^{2}$

Weight of steel framing, office floor

$500 \mathrm{~N} / \mathrm{m}^{2}$

Weight of steel framing, institutional floor

$750 \mathrm{~N} / \mathrm{m}^{2}$

Reinforced concrete beam/girder/slab floor system, office

$4000 \mathrm{~N} / \mathrm{m}^{2}$

The non-structure dead load may also be specified by allowance, known as the superimposed dead load. Values of superimposed dead load used in commercial/institutional construction range between $750-1250 \mathrm{~N} / \mathrm{m}^{2}$.

In other cases, the determination of the dead load involves reading the building plans, estimating the unit weight of the building components and summing these quantities in a conservative manner to determine the dead load. The weights of commonly used building materials are available (US) in the AISC Steel Construction Manual (2017) or Architectural Graphic Standards (2016). In the UK, these data are available in BS 648 Schedule of Weights of Building Materials. (1964). (Although no longer an active standard, this document has a very complete list of the weights of building materials.)

Example Dead Load Determination: Steel Framed Office Building (Refer to Figure S1.2)

\section{US}

A 33 foot $\times 33$ foot bay of an office building is provided with four infill beams (five spaces) spaced 6.6 feet apart. The concrete floor consists of 4.5 in normal weight concrete. Girders are W $24 \times 55$. Infill beams and are $\mathrm{W} 18 \times 35$. Find the total dead load on each infill beam in $\mathrm{lbs} / \mathrm{ft}$. Include beam self-weight by an allowance. Find the total dead load for one bay of the girders and beams alone. (in lbs.) Convert to an equivalent floor load (lbs/ $\left.\mathrm{ft}^{2}\right)$

Find the equivalent floor load on the infill beam in $\mathrm{lbs} / \mathrm{ft}^{2}$. Include beam self-weight.

Find the total dead load on each girder

Floor slab $\frac{4.5 \mathrm{in}}{12 \mathrm{in} / \mathrm{ft}} \times 150 \frac{\mathrm{lbs}}{f t^{3}}=56 \mathrm{lb} / f \mathrm{t}^{2}$
$\begin{array}{ll}\text { Floor finish } & 2 \mathrm{lb} / \mathrm{ft}^{2} \\ \text { Ceiling finish } & 2 \mathrm{lb} / \mathrm{ft}^{2} \\ \text { Fire Protection } & 3 \mathrm{lb} / \mathrm{ft}^{2} \\ \text { Lighting } & 5 \mathrm{lb} / \mathrm{ft}^{2} \\ \text { Mechanical } & 10 \mathrm{lb} / \mathrm{ft}^{2}\end{array}$

Total Dead Load $78 \mathrm{lb} / \mathrm{ft}^{2}$ This can be rounded to $80 \mathrm{lb} / \mathrm{ft}^{2}$

A superimposed dead load allowance of $15-25 \mathrm{lbs} / \mathrm{ft}^{2}$ is often used in place of itemizing the italicized items above. 
Dead Load of Beams

In one bay there are five $\mathrm{W} 18 \times 35$ (the two perimeter beams are half in one bay and half in the adjacent bay).

$$
5 \times 33 \mathrm{ft} \times 35 \mathrm{lb} / \mathrm{ft}=5800 \mathrm{lb}
$$

Two half W $24 \times 55$ (both W $24 \times 55$ are on the boundary with adjacent bay. To avoid double counting, we take two halves)

$$
1 \times 33 \mathrm{ft} \times 55 \mathrm{lb} / \mathrm{ft}=1820 \mathrm{lb}
$$

Converted to an equivalent uniform in a bay of size $33 \mathrm{ft} \times 33 \mathrm{ft}$

$$
7620 \mathrm{lb} \div(33 \mathrm{ft})^{2}=7 \mathrm{lb} / \mathrm{ft}^{2}
$$

$10 \mathrm{lb} / \mathrm{ft}^{2}$ is a suitable approximate value for steel framing for an office building.

Total floor load for infill beam $=6.6 \mathrm{ft}(80+10) \mathrm{lb} / \mathrm{ft}^{2}=590 \mathrm{lb} / \mathrm{ft}$

Total floor load girder $33 \mathrm{ft}(80+10) \mathrm{lb} / \mathrm{ft}^{2}=2970 \mathrm{lb} / \mathrm{ft}$

\section{UK}

A $10 \mathrm{~m} \times 10 \mathrm{~m}$ bay of an office building is provided with four infill beams (five spaces) spaced $2 \mathrm{~m}$ apart. The concrete floor consists of $120 \mathrm{~mm}$ normal weight concrete. Girders are UB $610 \times 229$ $\times 140$. Infill beams and are UB $457 \times 152 \times 82$. Find the total dead load on each infill beam in $\mathrm{lbs} / \mathrm{ft}$ include beam self-weight by an allowance, calculated below)

Find the total dead load for one bay of the girders and beams alone. (in $\mathrm{kg}$ ) Convert to an equivalent floor load $\left(\mathrm{N} / \mathrm{m}^{2}\right)$

Find the equivalent floor load for on the infill beam in $\mathrm{kg} / \mathrm{m}$ (include beam self-weight)

Find the total dead load on each girder $\mathrm{kg} / \mathrm{m}$

Floor slab $0.12 \mathrm{~m} \times 2300 \frac{\mathrm{kg}}{\mathrm{m}^{3}}=276 \frac{\mathrm{kg}}{\mathrm{m}^{2}}=2750 \mathrm{~N} / \mathrm{m}^{2}$

$\begin{array}{ll}\text { Floor finish } & 100 \mathrm{~N} / \mathrm{m}^{2} \\ \text { Ceiling finish } & 100 \mathrm{~N} / \mathrm{m}^{2} \\ \text { Fire Protection } & 150 \mathrm{~N} / \mathrm{m}^{2} \\ \text { Lighting } & 250 \mathrm{~N} / \mathrm{m}^{2} \\ \text { Mechanical } & 500 \mathrm{~N} / \mathrm{m}^{2} \\ \text { Total Dead Load } & 3850 \mathrm{~N} / \mathrm{m}^{2} \text { This would be rounded to } 4000 \mathrm{~N} / \mathrm{m}^{2} \text {. }\end{array}$

Dead Load of Beams

In one bay there are five UB475 $\times 152 \times 82$ beams (the two perimeter beams are half in one bay and half in the adjacent bay.

$$
5 \times 10 \mathrm{~m} \times 52 \mathrm{~kg} / \mathrm{m}=2600 \mathrm{~kg}
$$

One UB $610 \times 229 \times 140$ (see above for rationale for counting a single beam)

$$
1 \times 10 \mathrm{~m} \times 82 \mathrm{~kg} / \mathrm{m}=820 \mathrm{~kg}
$$


Converted to an equivalent uniform in a bay of size $10 \mathrm{~m} \times 10 \mathrm{~m}$

$$
3420 \div(10 \mathrm{~m})^{2}=34.2 \mathrm{~kg} / \mathrm{m}^{2}=340 \mathrm{~N} / \mathrm{m}^{2}
$$

$500 \mathrm{~N} / \mathrm{m}^{2}$ is a suitable approximate value for steel framing for an office building.

Total floor load for infill beam $=2 \mathrm{~m}(4000+500) \mathrm{N} / \mathrm{m}^{2}=9 \mathrm{kN} / \mathrm{m}$

Total floor load girder $=10 \mathrm{~m}(4000+500) \mathrm{N} / \mathrm{m}^{2}=45 \mathrm{kN} / \mathrm{m}$

\section{Figure S1.2. Building frame for dead and live load determination.}

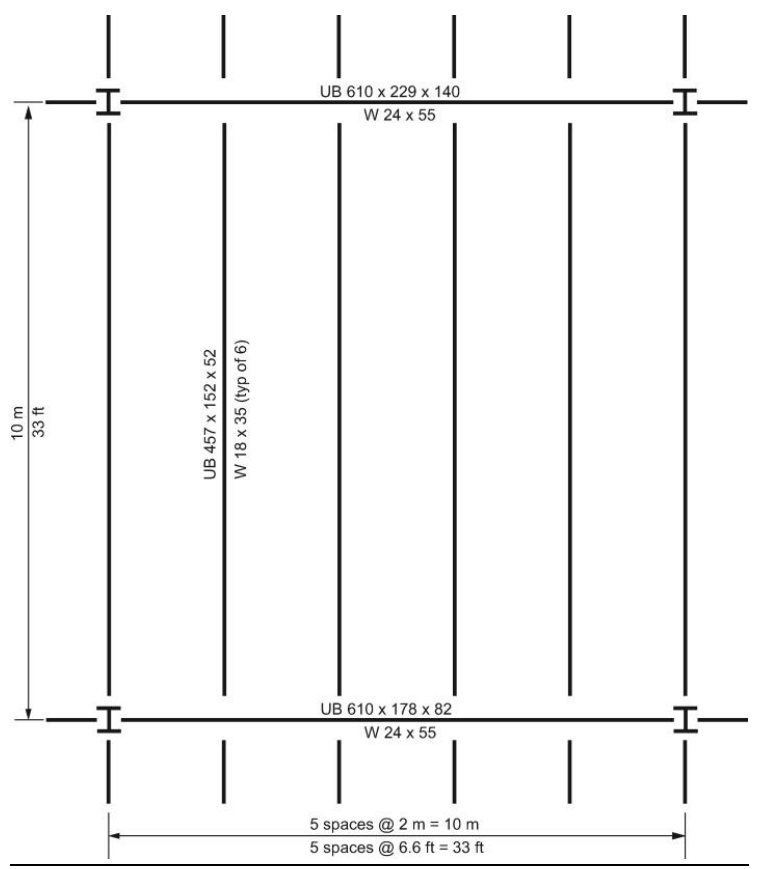

The calculation of live load

The live load to be used in the design of a building is determined by looking up on a table of live loads in the prevailing building code. An excerpt from the ASCE (2015) is presented below.

US

Typical values of the design live load are

Residential Live Load

$40 \mathrm{lbs} / \mathrm{ft}^{2}$

Office Live Load $50 \mathrm{lbs} / \mathrm{ft}^{2}$

Corridors-First Floor $100 \mathrm{lbs} / \mathrm{ft}^{2}$

Corridors-Second Floor and above

$80 \mathrm{lbs} / \mathrm{ft}^{2}$

The live load acting on an element of a structure is calculated similarly to the dead load. From the load per unit area, the area supported by an element is applied to determine the total load on the beam, girder, or column. 
UK

Typical values of floor live load

Residential Live Load

$200 \mathrm{~N} / \mathrm{m}^{2}$

Office Live Load

$250 \mathrm{~N} / \mathrm{m}^{2}$

Corridors-Ground Floor

$500 \mathrm{~N} / \mathrm{m}^{2}$

Corridors-First Floor and Above

$400 \mathrm{~N} / \mathrm{m}^{2}$

There are other refinements to the calculation of live load, such as reduction of live loads for elements that support a greater area. These questions would be taken up by a textbook on calculation-based methods of structural design.

\section{The calculation of snow load}

Finding snow loads on buildings involves look-up on a map of expected ground snow load values, and some further modifications to the ground snow load required by the exposure and configuration of the building in question. In temperate regions of North America roof snow loads range from $20 \mathrm{lbs} / \mathrm{ft}^{2}$ to as much as $100 \mathrm{lbs} / \mathrm{ft}^{2}$ in northern regions, mountainous regions, or regions to the south and east the Great Lakes.

The most complicated aspect of snow load calculation is the calculation of drift loads. A reader wishing to learn how to calculate drift loads is invited to consult ASCE (2015), Chapter 7

In Canada, rather than using a ground snow load map, snow loads are determined by consulting the National Research Council of Canada (2015) National Building Code Section 4.1.6. and Appendix C. These loads range similarly to US snow loads from approximately $1000 \mathrm{~N} / \mathrm{m}^{2}$ to $5000 \mathrm{~N} / \mathrm{m}^{2}$.

\section{Support reactions on a simply supported beam}

When the load and support conditions of a beam are known, it is possible to calculate the support reactions. The support reactions on a beam subjected to gravity load (acting downwards) are upwards-acting forces that resist the effect of the gravity loads. The fundamental notion of equilibrium of forces and moments is applied to the calculation of the reactions. The equations of equilibrium for plane forces are

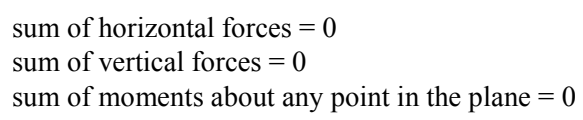

For instance, considering the partially loaded beam shown in Figure S1.3

\section{US}

The total weight of $10 \mathrm{k}$ is divided between the two support reactions. The way in which they are divided depends on the moment equililbrium of the load and the reactions. To assess the moment equilibrium, it is necessary to assign a center of moments, say the left support. The weight will develop a moment of $10 \mathrm{k} \times 15$ feet. $=150 \mathrm{ft}-\mathrm{k}$ about the left support, while the right reaction will develop a moment of $R_{R} \times 20$ feet. Since the sum of these two moment values is 0 , the right reaction must be $15 / 20 \times 10 \mathrm{k}=7.5 \mathrm{k}$, and the left reaction must be $2.5 \mathrm{k}$. 


\section{UK}

The total weight of $50 \mathrm{kN}$ is divided between the two support reactions. The way in which they are divided depends on the moment equililbrium of the load and the reactions. To assess the moment equilibrium, it is necessary to assign a center of moments, say the left support. The weight will develop a moment of $50 \mathrm{kN} \times 4.5$ $\mathrm{m} .=225 \mathrm{kN}-\mathrm{m}$ about the left support, while the right reaction will develop a moment of $\mathrm{R}_{\mathrm{R}} \times 6 \mathrm{~m}$. Since the sum of these two moment values is 0 , the right reaction must be $4.5 / 6 \times 50 \mathrm{kN}=37.5 \mathrm{kN}$, and the left reaction must be $12.5 \mathrm{kN}$.

\section{Figure S1.3. Partially loaded beam example}
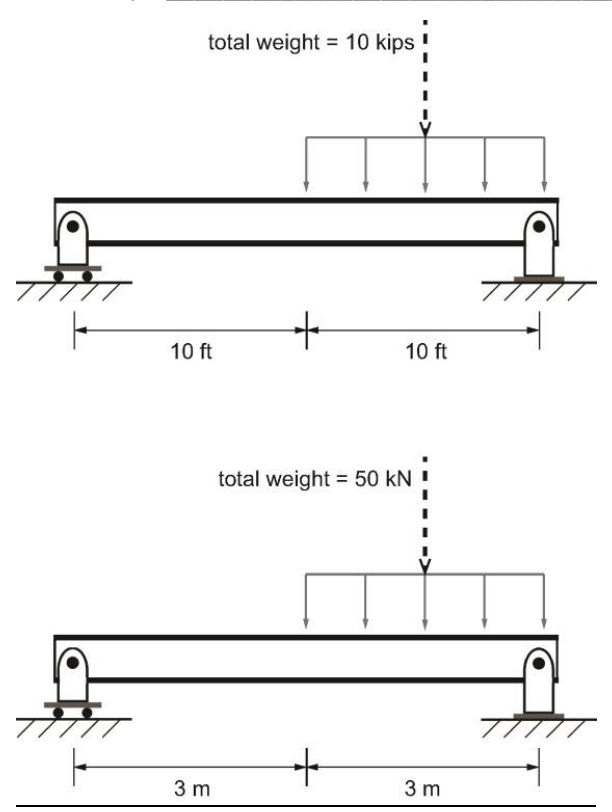

A further example is given by the bay of a steel framed floor described above in the dead load discussion and in Figure S1.2, using the full floor load on each beam. The present task is to find the end reactions at each of the infill beams, then to draw a loading diagram for the girders and find the reaction at each end of the girders.

On a symmetrically loaded beam, following the same procedure shows that half of the load is distributed to each support.

\section{US}

Beams

Total dead load

$90 \mathrm{lb} / \mathrm{ft}^{2} \times 6.6$ foot spacing $\times 33$ foot $\mathrm{span}=19600 \mathrm{lb}=19.6 \mathrm{kip}$

Total live load

$50 \mathrm{lb} / \mathrm{ft}^{2} \times 6.6 \mathrm{ft} \times 33 \mathrm{ft}=10.9 \mathrm{kip}$

Reaction $=15.4$ kip (symmetric beam) 


\section{UK}

Beams

Total dead load

$4500 \mathrm{~N} / \mathrm{m}^{2} \times 2 \mathrm{~m}$ spacing $\times 10 \mathrm{~m} \mathrm{span}=90 \mathrm{kN}$

Total live load

$2500 \mathrm{~N} / \mathrm{m}^{2} \times 2 \mathrm{~m} \times 10 \mathrm{~m}=50 \mathrm{kN}$

Reaction $=70 \mathrm{kN}$

The girder loading diagram that results from the reactions found for each infill beam is shown in Figure S1.4. There are four load points on each girder. Each of these load points receives the reaction from an infill beam from each of the adjacent bays ( 2 infill beams at each load point)

Figure S1.4. Girder Loading Diagram
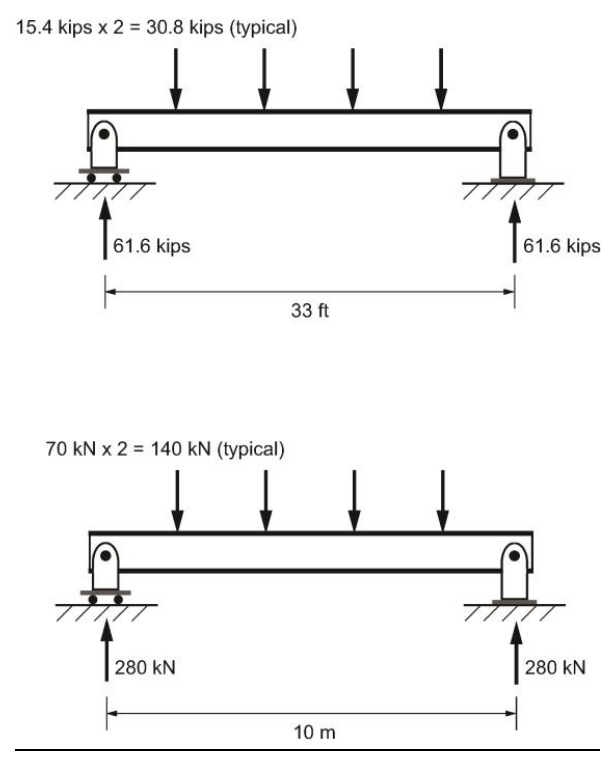

\section{Load Paths for Gravity-Loaded Structural Members}

In this discussion, we will concentrate on qualitative tracing of the load path, although it is equally possible to consider this matter quantitatively. Onouye and Kane (2012), Chapter 4, present some examples of the procedure of completing a quantitative load trace.

A qualitative load trace is a description of how the loads placed on a structure are carried into the foundation of the building and hence to the ground. Such a procedure can consider either vertical or lateral loads. The load path for lateral loads is included in the material on wind loads in Chapter 10 of the book.

In the first example, we will consider a simple wooden residential structure, such as the diagram of platform framing from Chapter 6 of Architectural Graphic Standards (American Institute of Architects 2016). If we consider a uniformly distributed load placed on the second floor of this structure, load from the deck is distributed to each of the joists supporting the floor. The joists in turn are supported by an exterior bearing wall 
and an interior bearing wall. That portion of the load the goes into the exterior bearing wall is carried through the wall studs, into the basement wall, and finally to the foundation. The load that is distributed to the interior bearing wall is carried similarly through the wall studs, but these are supported by a steel beam running the length of the basement. The loads from the steel beam are distributed to the columns supporting the steel beam, and, finally, to the foundation. Figure S1.5 shows this as a diagram, while Figure S1.6 depicts each of the elements in this load path.

Figure S1.5. Load Path Diagram for Framed Residence

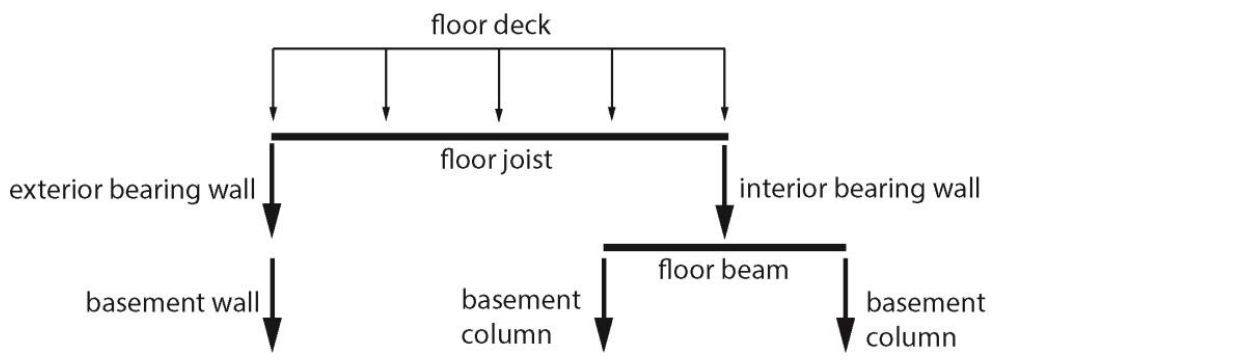

Figure S1.6. Description of Load Path Elements for Framed Structure (Reprinted with permission from Architectural Graphic Standards, Wiley and Sons.

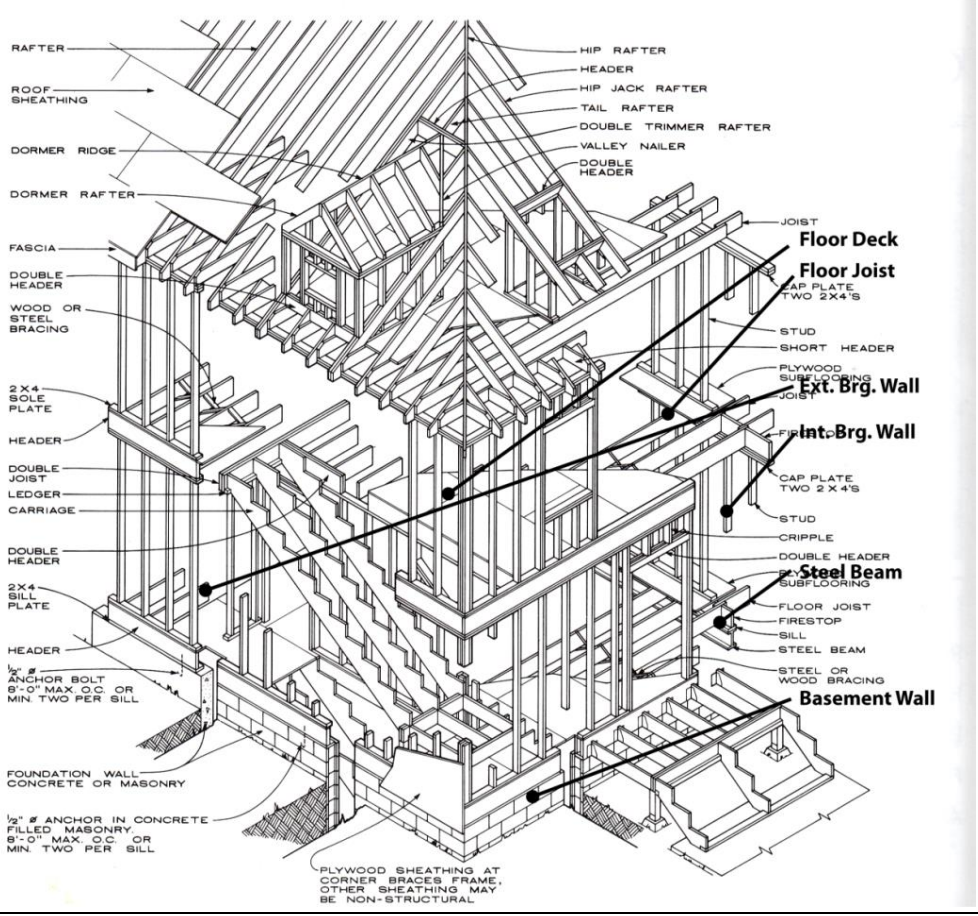

The load path for gravity loads in an office building such as that shown in the steel bay example above is illustrated schematically in Figure S1.7 and in Figure S1.8. It will be noted that the loads on upper floor beams, girder and slab do not contribute to the loads on those of the lower floors, but that the column loads are cumulative through all the floors of the building. 


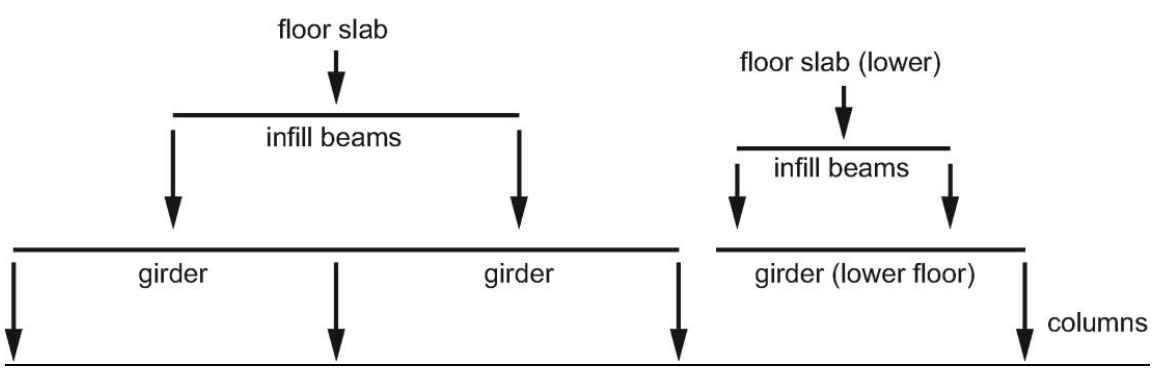

Figure S1.8. View of Steel Framed Structure

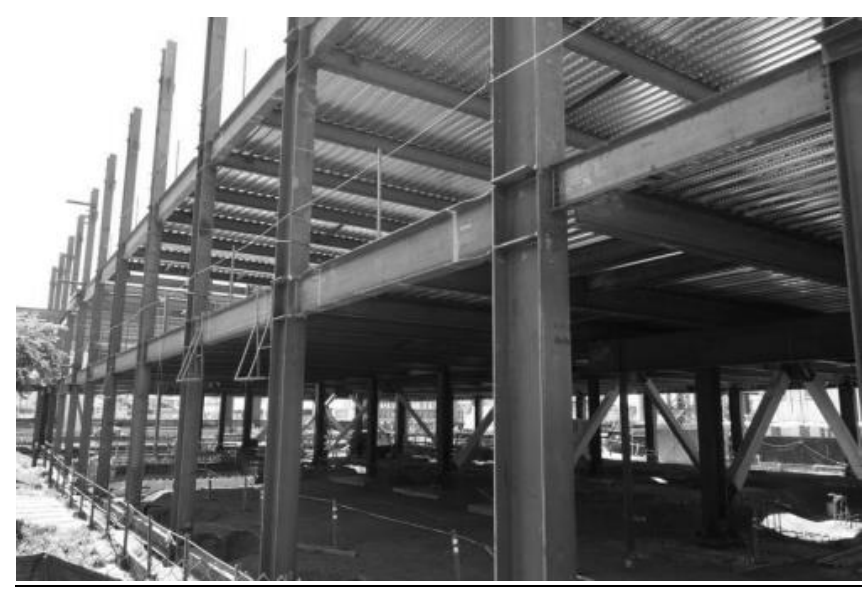

\section{Beams}

\section{Beam loading and support reactions.}

We will only discuss the simplest cases of beam reactions. However, the reactions of the beam are calculated similarly for all loading magnitudes and locations on a beam. The simply supported, uniformly loaded case used above describes a large proportion of the loading encountered on a beam in structural design.

Internal forces in a beam

The internal forces in a beam that are of interest generally in design are the internal shear and the internal bending moment.

Beam shear. The internal shear is defined as the force perpendicular to the beam axis that is required to restore equilibrium in a cut section of the beam. This is illustrated in Figure S1.9 for the loading example of the girder. 
Figure S1.9. Calculation of Internal Shear
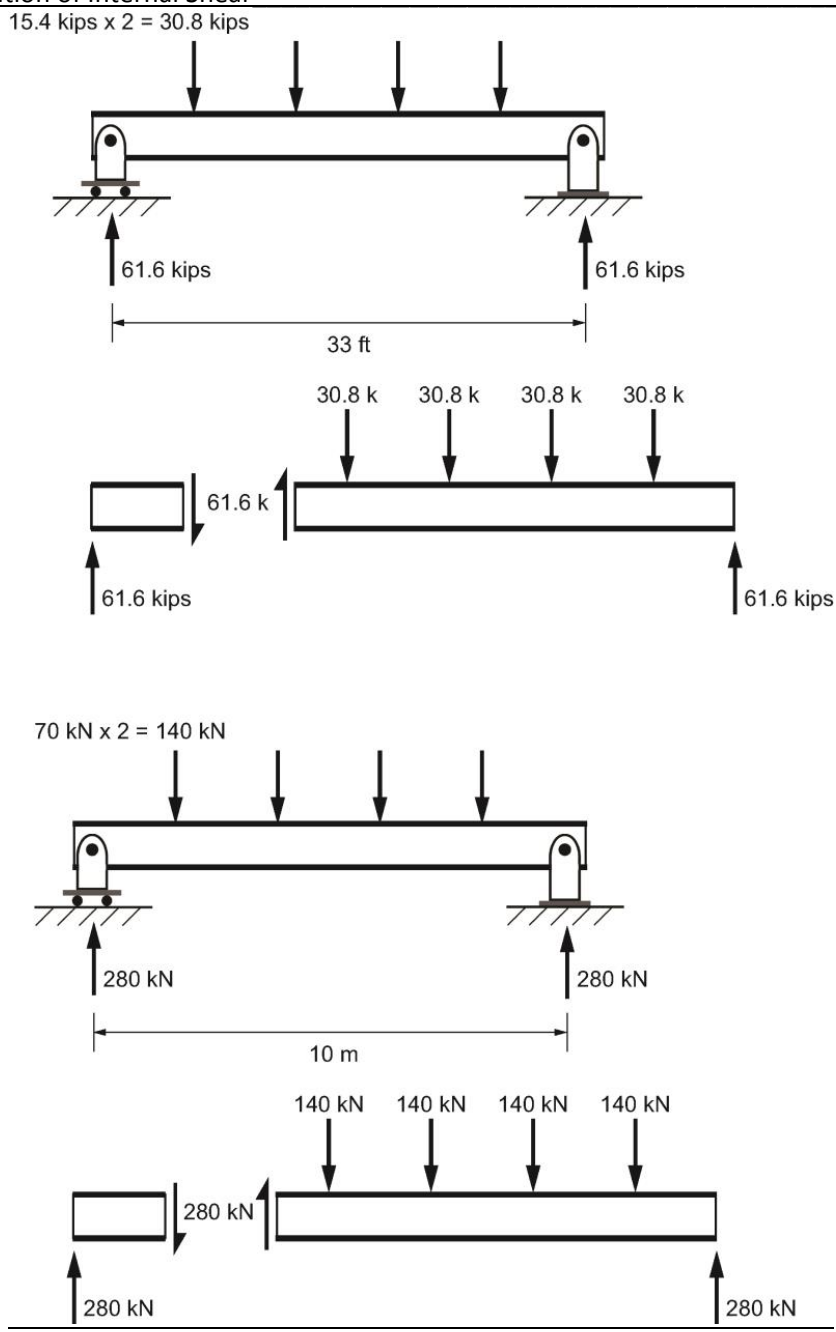

US

If a cut is taken near the left support, the free body diagram of the beam will be as shown in Figure S1.9. For vertical force equilibrium, a force of $61.6 \mathrm{k}$ (downward) is needed at the left side of the cut, while a force of $123.2 \mathrm{k}-61.6 \mathrm{k}=61.6 \mathrm{k}$ (upward) is needed at the right side of the cut.

A similar procedure gives a shear of 30.8 between the first and second load and a shear of 0 at midspan. It is customary to plot the shear along the length of the beam in a shear diagram. This is demonstrated after the discussion of bending moments below.

\section{UK}

For vertical force equilibrium, a force of $280 \mathrm{kN}$ (downward) is needed at the left side of the cut, while a force of $560 \mathrm{kN}-280 \mathrm{kN}=280 \mathrm{kN}$ (upward) is needed at the right side of the cut.

If a cut is taken near the left support, the free body diagram of the beam will be as shown in Figure S1.9 
A similar procedure gives a shear of $140 \mathrm{kN}$ between the first and second load and a shear of 0 at midspan. It is customary to plot the shear along the length of the beam in a shear diagram. This is demonstrated after the discussion of bending moments below.

Beam bending moment: Bending moment is calculated similarly to beam shear. The beam is cut at a specific location, and moment equilibrium is investigated on the two cut portions of the beam. The bending moment is required to restore moment equilibrium in a portion of the beam. We will calculate bending moments on the basis of the diagram shown in Figure S1.10. In this case, for the same beam, we cut successively at each of the two left-hand load points.

Figure S1.10. Calculation of Bending Moment

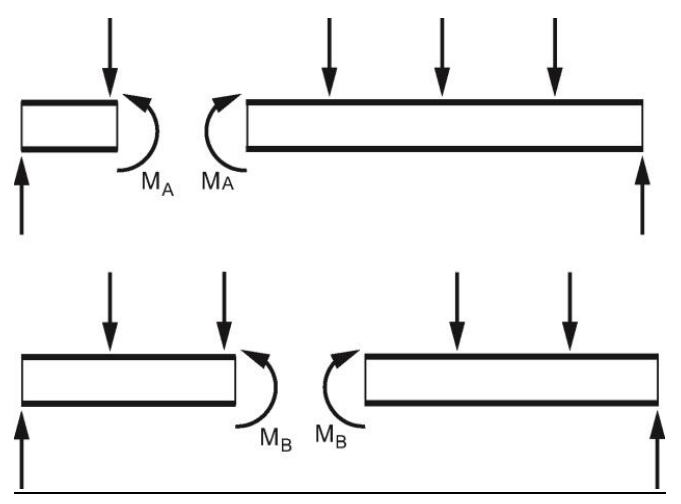

\section{US}

Taking moments about point $\mathrm{A}$, the point where the beam was cut $-61.6 \mathrm{k} \times 6.6 \mathrm{ft}+\mathrm{M}_{\mathrm{A}}=0 ; \mathrm{M}_{\mathrm{A}}=406 \mathrm{ft}-\mathrm{k}$

It is somewhat more complicated to take moments of the right side of the cut of the beam about $\mathrm{A}$ $61.6 \mathrm{k} \times 26.4 \mathrm{ft}-30.8 \times 19.8 \mathrm{ft}-30.8 \mathrm{k} \times 13.2 \mathrm{ft}-30.8 \mathrm{k} \times 6.6 \mathrm{ft}-\mathrm{M}_{\mathrm{A}}=0 ; \quad \mathrm{M}_{\mathrm{A}}=406 \mathrm{ft}-\mathrm{k}$

Taking moments about point $\mathrm{B}$, the point where the beam was cut $-61.6 \mathrm{k} \times 13.2 \mathrm{ft}-30.8 \times 6.6 \mathrm{ft}+\mathrm{M}_{\mathrm{A}}=0 ; \quad \mathrm{M}_{\mathrm{A}}=610 \mathrm{ft}-\mathrm{k}$

It is somewhat more complicated to take moments of the right side of the beam about $\mathrm{A}$ $61.6 \mathrm{k} \times 19.8 \mathrm{ft}-30.8 \times 13.2 \mathrm{ft}-30.8 \mathrm{k} \times 6.6 \mathrm{ft}-\mathrm{M}_{\mathrm{A}}=0 ; \quad \mathrm{M}_{\mathrm{A}}=610 \mathrm{ft}-\mathrm{k}$

\section{UK}

Taking moments about point $\mathrm{A}$, the point where the beam was cut $--280 \mathrm{kN} \times 2 \mathrm{~m}+\mathrm{M}_{\mathrm{A}}=0 ; \mathrm{M}_{\mathrm{A}}=560 \mathrm{kN}-\mathrm{m}$

It is somewhat more complicated to take moments of the right side of the beam about $\mathrm{A}$

$280 \mathrm{kN} \times 8 \mathrm{~m}-140 \mathrm{kN} \times 6 \mathrm{~m}-140 \mathrm{kN} \times 4 \mathrm{~m}-140 \mathrm{kN} \times 2 \mathrm{~m}-\mathrm{M}_{\mathrm{A}}=0 ; \quad \mathrm{M}_{\mathrm{A}}=560 \mathrm{kN}-\mathrm{m}$

Taking moments about point $\mathrm{B}$, the point where the beam was cut $-280 \mathrm{kN} \times 4 \mathrm{~m}-140 \mathrm{kN} \times 2 \mathrm{~m}+\mathrm{M}_{\mathrm{A}}=0 ; \quad \mathrm{M}_{\mathrm{A}}=840 \mathrm{kN}-\mathrm{m}$ It is somewhat more complicated to take moments of the right side of the beam about $\mathrm{A}$ $280 \mathrm{kN} \times 6 \mathrm{~m}-140 \mathrm{kN} \times 4 \mathrm{~m}-140 \mathrm{kN} \times 2 \mathrm{~m}-\mathrm{M}_{\mathrm{A}}=0 ; \quad \mathrm{M}_{\mathrm{A}}=840 \mathrm{kN}-\mathrm{m}$ 
The bending moments and the beam shear can be diagrammed along the length of the beam. The result for this beam is shown in Figure S1.11. It is observed that the area under the shear diagram (considering positive and negative signs of areas above and below the axis) at any point is equal to the bending moment. Thus, the area under half the shear diagram is equal to the bending moment at midspan. Either of the approaches given above: cutting the beam and calculating the bending moment directly, or drawing diagrams, allows the development of simple equations for the bending moment based on commonly-occurring conditions. The following are examples of these formulas, which are very frequently used. Other formulas can be found in the AISC Manual of Steel Construction and in many other references

simply supported beam, uniformly distributed load $\mathrm{w} ; \mathrm{M}=\mathrm{wL}^{2} / 8$

cantilever beam, uniformly distributed load $\mathrm{w} ; \mathrm{M}=\mathrm{wL}^{2} / 2$

simply supported beam, single concentrated load $\mathrm{P}$ at center; $\mathrm{M}=\mathrm{PL} / 4$

cantilever beam, single concentrated load $\mathrm{P}$ at end; $\mathrm{M}=\mathrm{PL}$

In all cases above, $L$ represents the span length of the beam.

Figure S1.11. Shear and Bending Moment Diagrams for Beam

Example
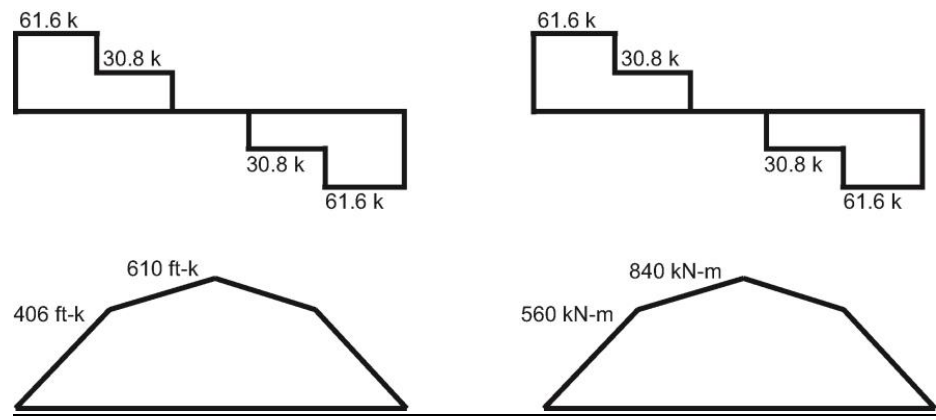

\section{Beam Bending Stresses}

The following is a very simplified discussion of the bending stresses. It applies only to the determination of the maximum bending stress in sections symmetrical about a horizontal axis, for which the section properties are available in a table. Other textbooks may give advice on unsymmetric sections, the calculation of bending stress at all points in the section, and the calculation of the section modulus for an arbitrary section. The treatment of bending stresses in reinforced or prestressed concrete sections is also a topic that may also be reviewed in textbooks devoted to that topic.

Beam bending stresses are related to beam bending moments through a geometrical section property of the beam, known as the section modulus. For standard sections in wood or steel, this property is tabulated, in the US, in AISC (2017), and in the UK in the Blue Book. (www.steelconstruction.info). The method of calculation is based on the formula

$$
\mathrm{f}_{\mathrm{b}}=\mathrm{M} / \mathrm{S}
$$

where $f_{b}$ is the maximum bending stress at the extremes of the cross section, $M$ is the bending moment, in units consistent with the units of the denominator, and $S$ is a section property known as the section modulus.

A simple example is the beam described above. Using (US) A W24 $\times 55\left(\mathrm{~S}=114 \mathrm{in}^{3}\right)$ or (UK) a UB $610 \times 178$ $\times 82\left(\mathrm{~S}=1870 \mathrm{~cm}^{3}\right)$

US $\quad \mathrm{f}_{\mathrm{b}}=610 \mathrm{ft}-\mathrm{k} \times 12 \mathrm{in} / \mathrm{ft} \div 114 \mathrm{in}^{3}=64.2 \mathrm{k} / \mathrm{in}^{2}$

UK $\mathrm{f}_{\mathrm{b}}=840 \mathrm{kN}-\mathrm{m} / 1870 \mathrm{~cm}^{3}=449 \mathrm{~N} / \mathrm{mm}^{2}$ 
The usual allowable bending stress in a beam is $30 \mathrm{k} / \mathrm{in}^{2}$ or $200 \mathrm{~N} / \mathrm{mm}^{2}$, so that the girders are undersized, in weight, although not necessarily in depth.

\section{Columns}

Columns are subject to two effects, crushing (material failure) and buckling (elastic stability failure). In fact, almost all columns of practical significance undergo a combination of effects. The tendency to crush is expressed by a capacity formula

$$
\mathrm{P}_{\mathrm{a}}=\mathrm{AF}_{\mathrm{a}}
$$

where $\mathrm{P}_{\mathrm{a}}$ is the axial force capacity of the material of the column, $\mathrm{A}$ is the cross-sectional area of the column, and $\mathrm{F}_{\mathrm{a}}$ is the maximum axial stress allowed in the column (on the basis of material strength).

Even elastic buckling is a more complicated phenomenon, while inelastic buckling (combined crushing and buckling) is significantly more complicated. The basic expression for elastic buckling is

$$
\mathrm{P}_{\mathrm{cr}}=\pi^{2} \mathrm{EI} / \mathrm{L}^{2}
$$

$\pi$ is a mathematical constant approximately equal to 3.14 , $\mathrm{E}$ is the modulus of elasticity of the material, I is the moment of inertia, a geometric property of the section chosen, and $\mathrm{L}$ is the length of the column. This formula is subject to the modification of putting it into terms of buckling stress, rather than force by dividing both sides by area, thus

$$
\mathrm{F}_{\mathrm{cr}}=\pi^{2} \mathrm{E} /(\mathrm{L} / \mathrm{r})^{2}
$$

The quantity $\mathrm{r}$ in the denominator, is the radius of gyration, obtained by dividing I/A in the numerator and redefining $\mathrm{r}^{2}=\mathrm{I} / \mathrm{A}$ The quantity $(\mathrm{L} / \mathrm{r})$ in the denominator is called the slenderness ratio, which is obtained by moving the radius of gyration to the denominator of the buckling stress equation. The slenderness ratio is a convenient, non dimensional expression of the tendency of a particular shape to buckle. If the slenderness ratio is high (over about 110, for a steel shape), the column will buckle elastically. If it is lower, it will behave inelastically in compression. Many other modifications to this formula are possible, and and many are used in practice, but we refer the reader to a more comprehensive summary of rational structural design, such as Ambrose (2011).

\section{Column loading}

The loading on a column is found from all of the beams, joists, or floor slab framing into the column. Unlike beam or joist loads, column loads are cumulative, including the sum of the loads from all of the floors framing into the column.

Example: Steel framed office building in previous example, shown in Figure S1.2, three stories + roof-roof loads will be taken to be the same as floor loads for simplicity

\section{US}

At each floor, column supports two girder reactions + two infill beam reactions. Additionally, allow 1000 lbs for the self-weight of the column at each floor level

Recall girder reaction $=61.6 \mathrm{k}$

Recall infill beam reaction $=30.8 \mathrm{k}$

Total column load at each floor $/$ roof $=92.4 \mathrm{k}+1 \mathrm{k}=93.4 \mathrm{k}$

Total column load $=93.4 \mathrm{k} \times 4=374 \mathrm{k}$

Column capacity

We will suppose the use of a W10 $\times 49\left(\mathrm{~A}=14.4 \mathrm{in}^{2} ; \mathrm{L}=144 \mathrm{in}, \mathrm{r}=2.54 \mathrm{in}\right)$

The maximum compressive stress is $374 \mathrm{k} / 14.4 \mathrm{in}^{2}=26 \mathrm{k} / \mathrm{in}^{2}<30 \mathrm{ok}$

The maximum buckling stress $=9.86\left(29,000 \mathrm{k} / \mathrm{in}^{2}\right) /(144 / 2.54)^{2}=89 \mathrm{k} / \mathrm{in}^{2}$. Even with a factor of safety of 2 or 3 applied, this is still greater than the material allowable stress. According to Table 4-1 in the Manual of Steel Construction, the allowable strength of this column is $341 \mathrm{k}$. The difference is due to 
the way that engineering steel design accounts for inelastic buckling. These distinctions are beyond the scope of this discussion.

\section{UK}

At each floor, column supports two girder reactions + two infill beam reactions. Additionally, allow $1000 \mathrm{~N}$ for the self-weight of the column at each floor level

Recall girder reaction $=280 \mathrm{kN}$

Recall infill beam reaction $=140 \mathrm{kN}$

Total column load at each floor $/$ roof $=281 \mathrm{kN}$

Total column load $=281 \mathrm{kN} \times 4=1120 \mathrm{kN}$

Column capacity

We will suppose the use of a UC $254 \times 254 \times 73\left(\mathrm{~A}=93.1 \mathrm{~cm}^{2} ; \mathrm{L}=4 \mathrm{~m} ; \mathrm{r}=6.48 \mathrm{~cm}\right)$

The maximum compressive stress is $1120 \mathrm{kN} / 93.1 \mathrm{~cm}^{2}=120 \mathrm{~N} / \mathrm{mm}^{2}<200 \mathrm{ok}$

The maximum buckling stress $=9.86\left(200000 \mathrm{~N} / \mathrm{mm}^{2}\right) /(400 / 6.48)^{2}=517 \mathrm{~N} / \mathrm{mm}^{2}$. Even with a factor of safety of 2 or 3 applied, this is still greater than the material allowable stress. According to the Interactive Blue Book Compression Resistance Table, the factored axial force capacity of this column is $2170 \mathrm{kN}$. The difference is due to the way that engineering steel design accounts for inelastic buckling. These distinctions are beyond the scope of this discussion.

\section{References}

Ambrose, James, Simplified Engineering for Architects and Builders. $11^{\text {th }}$ edition., New York, John Wiley and Sons, 2011.

American Institute of Steel Construction (AISC), Steel Construction Manual, Fifteenth Edition, Chicago, 2017.

American Institute of Architects, Architectural Graphic Standards, Twelfth Edition, New York, John Wiley and Sons, 2016.

British Standards Institution, Schedule of Weights of Building Materials, BS648, London (1964).

American Society of Civil Engineers (ASCE), ASCE 7-15, Minimum Design Loads for Buildings and Other Structures, Reston, VA, 2015

National Research Council of Canada. National Building Code. Ottawa, 2015.

The Blue Book, steelforlifebluebook.co.uk, accessed 4 June 2018 


\section{Supplementary Chapter 2. Exercise Solutions.}

\section{Solution to Chapter 2 Exercises.}

\section{Solution to Exercise 2.1}

\section{US}

Unreinforced masonry

Buttress height $/$ width $=20$ feet $/ 3$ feet $=6.333$, which requires a semicircular arch, or preferably a gothic arch . Extra weight of masonry above will make buttress more effective, so a semicircular arch will be OK.

Span 20 feet. Try rise $=10$ feet. $\mathrm{S} / \mathrm{R}=0.500$

Arch thickness $=0.025 \mathrm{~s}^{2} / \mathrm{R}=0.025(20)^{2} / 10=1$ foot

Reinforced concrete; use 6 in thickness

\section{UK}

Unreinforced masonry

Buttress height $/$ width $=6000 \mathrm{~mm} / 1000 \mathrm{~mm}=6$, which requires a a semicircular arch, or preferably a gothic arch. Extra weight of masonry above will make buttress more effective, so a semicircular arch will be OK.

Span $6000 \mathrm{~mm}$. Try rise $=3000 \mathrm{~mm}$, so $\mathrm{S} / \mathrm{R}=0.500$

Arch thickness $=0.025 \mathrm{~s}^{2} / \mathrm{R}=300 \mathrm{~mm}$

Reinforced concrete $=$ use $150 \mathrm{~mm}$ thick arch.

\section{Solution to Exercise 2.2}

Main nave arch, for example. Span $=18$ feet; rise $=18$ feet. Required thickness $=0.45$ feet; use 6 in. -8 in. thick arch.

\section{Solution to Exercise 2.3}

\section{See Figure S2.1}

\section{Figure S2.1}

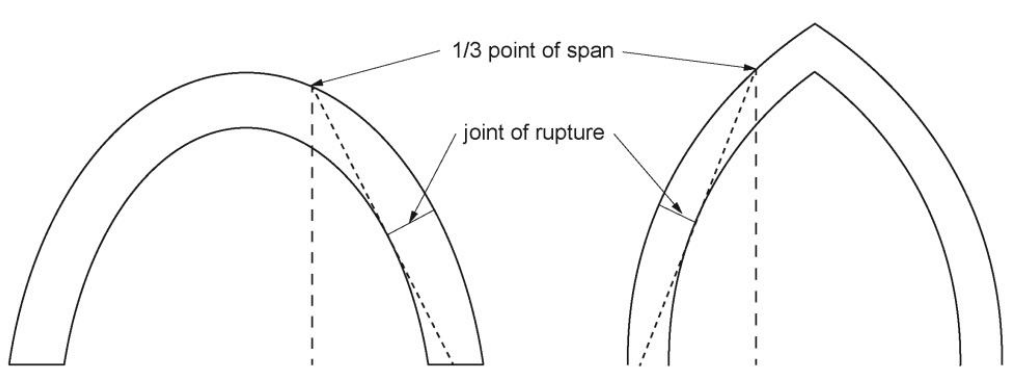




\title{
Supplementary Chapter 3. Exercise Solutions and Supplementary Exercises
}

\author{
Solutions to Chapter 3 Exercises
}

Solution to Exercise 3.1

\section{US}

Roof joist span/depth $=50$ feet $/ 18=30$ in, required wall height $=9$ feet +1 foot +2.5 feet $=12 \mathrm{ft} .8$ in.

Floor joist span/depth $=50$ feet $/ 18=30$ in, required wall height $=11$ feet +2 feet +2.5 feet $=16 \mathrm{ft}$. 0 in.

Second floor walls, use 8 in. CMU grouted (height limit $20 \times 8$ in. $=13 \mathrm{ft} .4 \mathrm{in}$.), or $12 \mathrm{in}$. ungrouted First floor walls, use 12 in. ungrouted (height limit $18 \times 12$ in $=18 \mathrm{ft} .0$ in.

Use 12 in. ungrouted for both walls.

UK

Roof joist depth $=10000 / 18=560 \mathrm{~mm}, 606$ prescribed by problem statement required wall height $=2700+606 \mathrm{~mm}=3400 \mathrm{~mm}$

Floor joist span/depth $=$ same as above required wall height $=3300 \mathrm{~mm}+606 \mathrm{~mm}=4000 \mathrm{~mm}$

Second floor walls, $200 \mathrm{~mm}$ CMU grouted (height limit $20 \times 200=4000 \mathrm{~mm}$ ), or $300 \mathrm{~mm}$ ungrouted First floor walls, 300 ungrouted (height limit $18 \times 300 \mathrm{~mm}=5400 \mathrm{~mm}$ Use $300 \mathrm{~mm}$ ungrouted for both first and second floor walls.

\section{Solution to Exercise 3.2}

\section{US}

Bearing walls $2 \times 4 @ 12$ inches (ground floor) Bearing walls $2 \times 4 @ 24$ inches (other floors) Non-bearing walls $2 \times 4 @ 24$ inches

\section{UK}

Bearing walls $38 \times 100 @ 300$ mm spacing (ground floor) Bearing walls $38 \times 100 @ 600$ mm spacing (other floors) Non-bearing walls $38 \times 100 @ 600$ mm spacing 


\section{Solution to Exercise 3.3}

Foundation in a non-retaining condition (left) 8 in. CMU grouted below grade.

Foundation in an earth-retaining condition, 12 in. grouted unreinforced, preferably 8 in. CMU grouted and reinforced.

\section{Solution to Exercise 3.4}

Per Table 3-2, 8 floors, possibly 10 floors. Beyond this height, use a concrete frame or steel frame is required for the support of the floors.

\section{Supplementary Exercises.}

Exercise S3.1. Design a non-bearing CMU wall supported at ground level and 40 feet (12000 mm) above ground.

Exercise S3.2. Using the Figure E10.2 as the plan, design load bearing walls between dwelling units for the following four conditions:

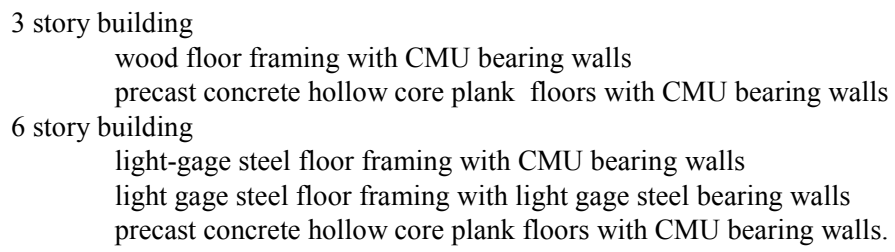

Exercise S3.3. Tilt-up wall design

A 200 foot $\times 300$ foot one story steel-framed warehouse is to have its walls built by the tilt-up method. The clear interior height is 22 feet, which requires that the top of steel be located at 25 feet above grade.

1) Determine the width, height and required thickness of the wall panels.

2) Lay out a pattern for casting the walls on the floor slab, leaving a 5 foot wide pour strip to accommodate the foundation. Identify the wall panels that will be stacked..

\section{Solutions to Supplementary Chapter 3 Exercises}

\section{Solution to Exercise S3.1}

US

Based on height:thickness ratios, even a reinforced 12 inch wall would not be sufficient. It is necessary to use regularly spaced pilasters having the correct span-thickness ratio. For reinforced CMU, the pilasters should have a span:thickness ratio of 24 , thus the pilasters are best at a size of $24 \mathrm{in} . \times 24 \mathrm{in}$. Unreinforced masonry between the pilasters requires a horizontal span: thickness ratio of 18 , so 12 foot spacing of the pilasters is required for 8 in. CMU. The final result is illustrated in Figure S3.1 


\section{UK}

Based on height:thickness ratios, even a reinforced $300 \mathrm{~mm}$ thick wall would not be sufficient. It is necessary to use regularly spaced pilasters having the correct span-thickness ratio. For reinforced CMU, the pilasters should have a span:thickness ratio of 24 , thus the pilasters are best at a size of $600 \mathrm{~mm} \times 600 \mathrm{~mm}$. Unreinforced masonry between the pilasters requires a horizontal span: thickness ratio of 18 , so $3600 \mathrm{~mm}$ spacing of the pilasters is required for $200 \mathrm{~mm}$ CMU. The final result is illustrated in Figure S3.1.

Figure S3.1 Layout of CMU wall with pilasters
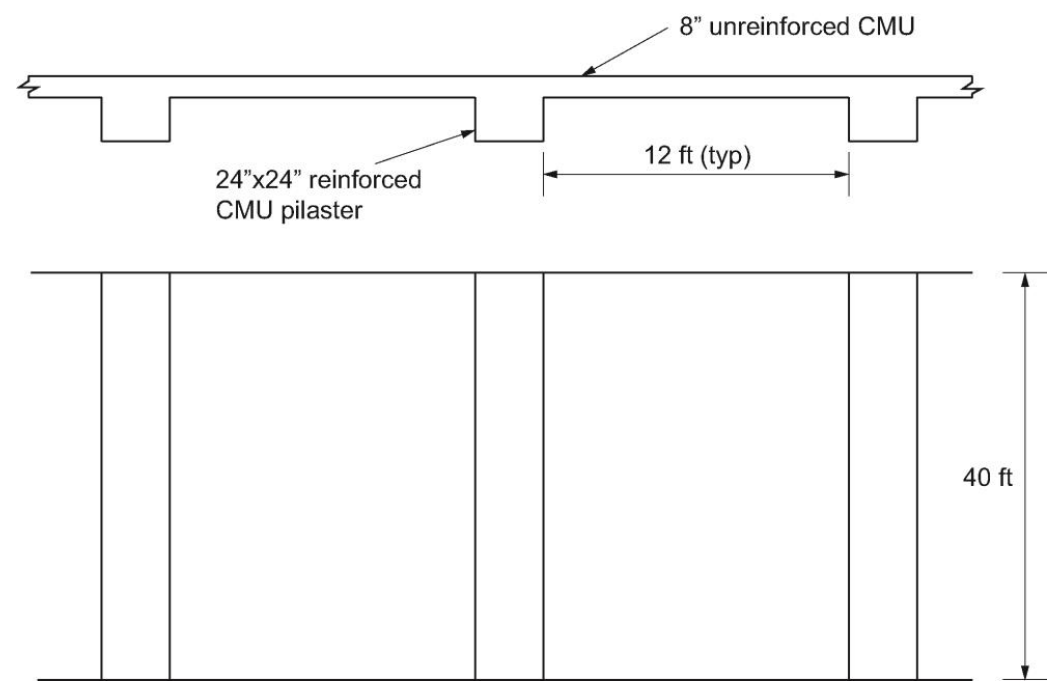

\section{Solution to Exercise S3.2}

Use Table 3.2 modified for lighter floor loads (wood or lightgage steel in place of precast concrete plank)

3 storey

wood floor framing concrete plank

6 storey

lightgage steel floor framing lightgage steel walls and floor concrete plank

\section{Solution to Exercise S3.3}

See Figure S3.2
8 in. ungrouted

8 in. grouted at ground floor, ungrouted above

8 in. grouted

6 in. lightgage steel studs: 12 in. spacing or doubled at ground floor 10 in. grouted 


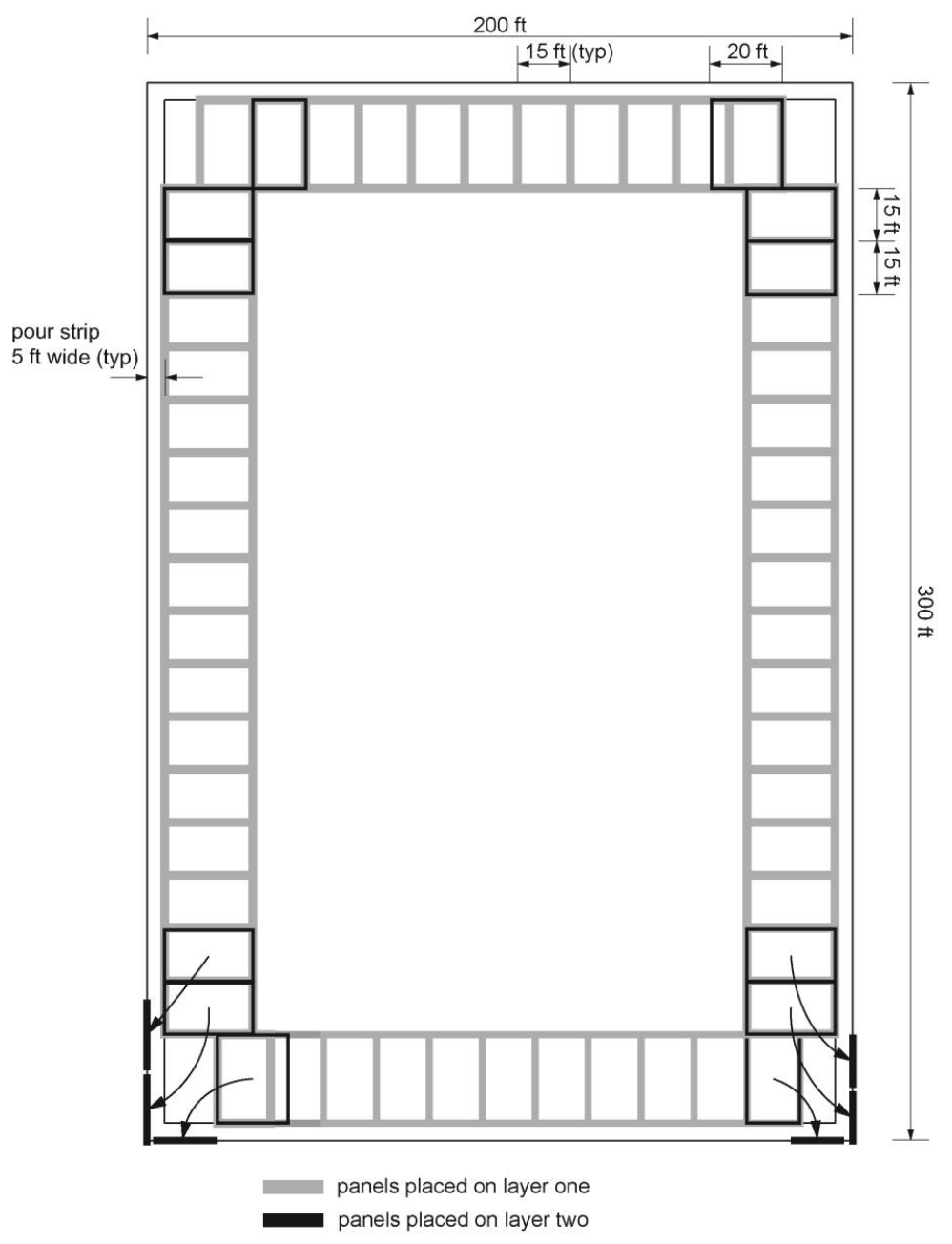




\title{
Supplementary Material for Chapter 4. Supplementary Material and Solutions to Exercises
}

\section{Supplementary Material on Column Design}

\author{
Semi-empirical Column Design
}

In this procedure, the loads on a steel column are estimated by using rough approximations of the loads on a building floor, multiplied by the number of floors, multiplied by the approximate area supported by an individual column. The area supported by a column is determined by drawing on the framing plan a rectangle around the column with its sides halfway to each of the adjacent columns.

Following the estimate of the loads, a column size can be determined by looking at column tables: in US practice, these tables are found in Table 4-1 of the Manual of Steel Construction. In the UK, these tables are found in the online Blue Book, and in Canada, these tables are found in the Handbook of Steel Construction. This procedure is illustrated in the example below.

Again, the reader is be cautioned that this semi-empirical procedure is only used to determine the required dimensions of the column, but cannot substitute for the size of the column determined by an appropriate engineering analysis.

Table S4.1. Example Floor Loads for semi-empirical column design

\begin{tabular}{lllll}
\hline $\begin{array}{l}\text { Building } \\
\text { Construction }\end{array}$ & Building Occupancy & $\begin{array}{l}\text { Approximate total } \\
\text { floor load } \\
\left(\mathrm{lb} / \mathrm{ft}^{2}\right)\end{array}$ & $\begin{array}{l}\text { Approximate floor } \\
\text { load } \\
\left(\mathrm{kN} / \mathrm{m}^{2}\right) \\
\text { Includes an } \\
\text { estimated partial } \\
\text { safety factor }\end{array}$ & $\begin{array}{l}\text { Roof load factor } \\
\text { (in low-moderate } \\
\text { snow regions) }\end{array}$ \\
\hline Concrete & & $15 \mathrm{kN} / \mathrm{m}^{2}$ & $70 \%$ \\
& Institutional & 200 & $10 \mathrm{kN} / \mathrm{m}^{2}$ & $70 \%$ \\
Steel & Business & 150 & $12 \mathrm{kN} / \mathrm{m}^{2}$ & $60 \%$ \\
& Institutional & 170 & $10 \mathrm{kN} / \mathrm{m}^{2}$ & $60 \%$ \\
Wood & Business & 150 & $3.5 \mathrm{kN} / \mathrm{m}^{2}$ & $50 \%$ \\
& Residential & 50 & $7 \mathrm{kN} / \mathrm{m}^{2}$ & $50 \%$ \\
\hline
\end{tabular}

\section{US}

For instance, for the column that is part of a rectangular 24 foot $\times 30$ foot grid as shown in Figure S4.1, Column B-2 is considered to support a floor area of $720 \mathrm{ft}^{2}$, while Column B-1 is considered to support a floor area of 360 feet $^{2}$.

\section{UK}

For instance, for the column that is part of a rectangular $7500 \mathrm{~mm} \times 9000 \mathrm{~mm}$ grid as shown in Figure S4.1, Column B-2 is considered to support a floor area of $67.5 \mathrm{~m}^{2}$, while Column B-1 is considered to support a floor area of $34 \mathrm{~m}^{2}$. 
Estimates of floor and roof loads vary with the construction material, occupancy and other factors. The values given in Table S4.1 can be used in the absence of more detailed information. The SI values have been increased by approximately $50 \%$ to account for the use of partial safety factors in the design of the columns. This step is necessary for the comparisons with published tables that we present in the examples and exercises.

Although for buildings greater than four floors, it is unnecessary to use the roof loads less than thefloor loads, in one through four story buildings it is necessary to acknowledge that the roof loads are usually less than the floor loads, by approximately the percentage that is presented in the Table.

\section{US}

A ten story steel framed office building, having the column layout shown in Figure S4.1, has a column load of approximately 10 floors $\times 720 \mathrm{ft}^{2} /$ floor $\times 150 \mathrm{lb} / \mathrm{ft}^{2}=1080 \mathrm{kips}$. Using Table $4-1$ of the AISC Manual of Steel Construction, Allowable Strength Design, and a floor-floor height of 12 feet, a W12 $\times 136$ is adequate. Note that the empirical design method suggests a 12 inch column to support ten floors.

\section{UK}

A ten story steel framed office building, having the column layout shown in Figure S4.1, has a column load of approximately 10 floors $\times 67.5 \mathrm{~m}^{2} /$ floor $\times 10 \mathrm{kN} / \mathrm{m}^{2}=6750 \mathrm{kN}$. Using the Universal Columns buckling resistance table, and a floor-floor height of $3500 \mathrm{~m}$, a UC $305 \times 305 \times 240$ is adequate. Note that the empirical design method suggests a $300 \mathrm{~mm}$ column to support ten floors.

\section{Canada}

A ten story steel framed office building, having the column layout shown in Figure S4.1, has a column load of approximately 10 floors $\times 67.5 \mathrm{~m}^{2} /$ floor $\times 10 \mathrm{kN} / \mathrm{m}^{2}=6750 \mathrm{kN}$. Using Column tables in the Handbook of Steel Construction and a floor-floor height of $3500 \mathrm{~m}$, a WWF310 $\times 253$ is adequate. Note that the empirical design method suggests a $300 \mathrm{~mm}$ column to support ten floors.

\section{The Rankine-Gordon formula for column design}

For the design of steel and wood columns, a different sort of empirical procedure may be appropriate. The principal means of designing such columns from the mid-1800's through the early 1900's was the application of the Rankine-Gordon formula. This formula can be used to calculate an allowable stress, which, when multiplied by the area of the proposed column, gives an allowable column axial force. In the empirical version of the formula, the numerator $f$ (allowable maximum compressive stress of the material) and appropriate empirically determined values of the constant $c$ for various materials and shapes are given in Table S4.2. (Crehore 1886). Because the denominator is dimensionless, modifications for systems of units are not required. Modifications to the effective length factor can be effected by increasing the value of the constant $a$, that is, by doubling $a$ for a fixed-fixed column (a more conservative approach is to multiply by 1.8). A reader interested in further exploration of the application of the Rankine-Gordon formula can refer to Boothby (2015).

The Rankine-Gordon formula for allowable axial stress in a column

$$
F_{a}=\frac{f}{1+\frac{l^{2}}{a d^{2}}}
$$

$F_{a}=$ allowable compressive stress in column

$l=$ length of column between weak axis supports

$d=$ characteristic least diameter of column

$a=$ constant determined from Table S4-3 
Figure S4.1. Column Layout for Semi-empirical Design Example

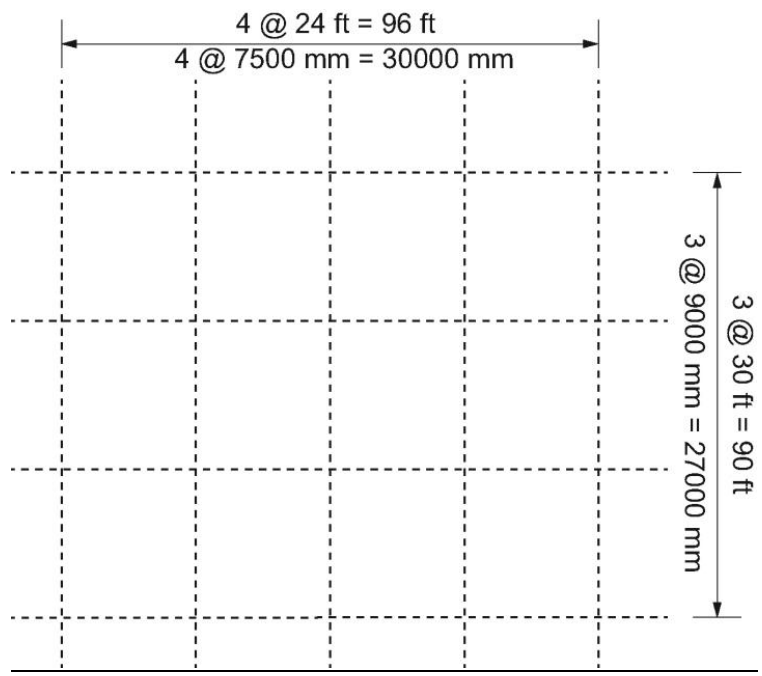

Table S4.2. Rankine-Gordon Coefficients

\begin{tabular}{lcc}
\hline \multicolumn{1}{c}{ Column Type } & $\mathrm{f}$ & $\mathrm{a}$ \\
\hline wood round & 1200 & 250 \\
wood rectangular & 1200 & 250 \\
Steel W-shape & 30000 & 1200 \\
Steel round & 27000 & 1200 \\
Steel Box & 27000 & 2000 \\
Steel cruciform & 22000 & 1000 \\
\hline
\end{tabular}

\section{US}

15 foot long $\mathrm{W}$-shape; 8 in = least dimension, pinned ends.

Column Load $=153$ kips

$F_{a}=21,100 \mathrm{lb} / \mathrm{in}^{2}$

$$
F_{a}=\frac{30 \mathrm{k} / \mathrm{in}^{2}}{1+\frac{180^{2}}{(1200) 8^{2}}}=21.1 \mathrm{k} / \mathrm{in}^{2}
$$

$\mathrm{W} 8 \times 31$ area $=9.13 \mathrm{in}^{2} ;$ stress $=153 \mathrm{k} / 9.13 \mathrm{in}^{2}=16,800 \mathrm{lb} / \mathrm{in}^{2}$ compressive stress $16,800 \mathrm{lb} / \mathrm{in}^{2}<21,100 \mathrm{lb} / \mathrm{in}^{2}$ allowable stress Note: Table 4.1 of the AISC Manual of Steel Construction gives allowable axial force as $230 \mathrm{k}$, that is $25.2 \mathrm{k} / \mathrm{in}^{2}$ 
UK

Example: $4500 \mathrm{~mm}$ long UC $203 \times 203 \times 46$ pinned ends.

Column Load $=684 \mathrm{kN}$

$$
F_{a}=\frac{200 \mathrm{~N} / \mathrm{mm}^{2}}{1+\frac{4500^{2}}{(1200) 203^{2}}}=141 \mathrm{~N} / \mathrm{mm}^{2}
$$

$F_{a}=141 \mathrm{~N} / \mathrm{mm}^{2}$

UC $203 \times 203 \times 46$ area $=58.7 \mathrm{~cm}^{2} ;$ stress $=684,000 \mathrm{~N} / 5870 \mathrm{~mm}^{2}=116 \mathrm{~N} / \mathrm{mm}^{2}$ compressive stress $116 \mathrm{~N} / \mathrm{m}^{2}<141 \mathrm{~N} / \mathrm{mm}^{2}$ allowable stress 


\section{Example and Exercises: semi-empirical calculation of column loads}

\section{Addendum to Example 4.1 (Example 4.1 is repeated below for convenience)}

\section{Example 4.1}

\section{US}

A steel-framed building is constructed with 32 foot $\times 28$ foot bays. The building height is 6 floors. Floor-floor height is $12 \mathrm{ft} .6$ in.. Design a steel column to support the floors and roof of this building.

Unsupported height $/$ width ratio (steel I-beam) $=12-20$; Try minimum 8 in. column

Column increases in size every four floors, so 8 in. for top four floors, 10 inches for bottom. preferable to use $\mathrm{W} 10$ column shape $(\mathrm{W} 10 \times 45$ through $\mathrm{W} 10 \times 119)(10 \mathrm{in}$. flange width)

\section{UK}

A steel-framed building is constructed with $10000 \mathrm{~mm} \times 8500 \mathrm{~mm}$ bays. The building height is 6 floors. Floor-floor height is $4000 \mathrm{~mm}$. Design a steel column to support the floors and roof of this building.

Unsupported height/width ratio (steel I-beam) = 12-20; Try minimum $203 \mathrm{~mm}$ column Column increases in size every four floors, so $203 \mathrm{~mm}$ for top four floors, $254 \mathrm{~mm}$ for bottom. Preferable to use UC $254 \times 254$ (weight $73 \mathrm{~kg} / \mathrm{m}$ through $167 \mathrm{~kg} / \mathrm{m}$ )

\section{Canada}

A steel-framed building is constructed with $10000 \mathrm{~mm} \times 8500 \mathrm{~mm}$ bays. The building height is 6 floors. Floor-floor height is $4000 \mathrm{~mm}$. Design a steel column to support the floors and roof of this building.

Unsupported height/width ratio (steel I-beam) = 12-20; Try minimum $200 \mathrm{~mm}$ column Column increases in size every four floors, so $200 \mathrm{~mm}$ for top four floors, $254 \mathrm{~mm}$ for bottom. Better to use WWF 250 (weight $73 \mathrm{~kg} / \mathrm{m}$ through $167 \mathrm{~kg} / \mathrm{m}$ )

\section{Example 4.1 by Semi-empirical method.}

\section{US}

Following the given data in Example 4.1, the approximate load on this column, resulting from a dead load of 80 $\mathrm{lb} / \mathrm{ft}^{2}$ and a live load of $50 \mathrm{lb} / \mathrm{ft}^{2}$ is 32 feet $\times 28$ feet $\times 130 \mathrm{lbs} / \mathrm{ft}^{2} \times 6$ floors $=698 \mathrm{kips}$. According to Table 4-1 of the AISC manual, a W10 $\times 100$ will work for a 12 foot height and a 700 kip unfactored load. 


\section{UK}

The total load is $3100 \mathrm{kN}$, resulting from a dead load of $4000 \mathrm{~N} / \mathrm{m}^{2}$ and a live load of $2500 \mathrm{~N} / \mathrm{m}^{2}$ but must be assessed according to Eurocode rules, that is, separating into a dead load of $2000 \mathrm{kN}$ and a live load of $1100 \mathrm{kN}$, to which partial safety factors are applied. According to the Interactive Blue Book (2017), a UC $203 \times 203 \times$ 127 , with a length of $3000 \mathrm{~mm}$, furnishes a resistance to factored load of $3330 \mathrm{kN}$, indicating that this column is probably somewhat undersized.

\section{Canada}

According to the Canadian version of this example, the total load is $3100 \mathrm{kN}$, but must be assessed according to Canadian rules, that is, separating into a dead load of $2000 \mathrm{kN}$ and a live load of $1100 \mathrm{kN}$, to which a partial safety factor is applied. According to the Handbook of Steel Construction (1985), a WWF $250 \times 250 \times 167$, with a length of $3000 \mathrm{~mm}$, furnishes a resistance to factored load of $4950 \mathrm{kN}$. This column has an $\mathrm{L} / \mathrm{r}$ ratio of $3000 / 250=12$. 


\section{Solutions to Chapter 4 Exercises}

\section{Solution to Exercise 4.1}

Required column size at ground floor $=\mathrm{L} / \mathrm{d}=12-20$; minimum 8 in., increase 2 in. for each four floors supported up to $14 \mathrm{in.}$

$\mathrm{L} / \mathrm{d}=15$ suggests a 12 in. column $(\mathrm{L}=15.33 \mathrm{ft})$. The actual columns are one size larger, the perimeter columns being W14 $\times 183$. Note that the column is part of the lateral force resisting system, which may increase the size of the column, and especially require a column with greater depth perpendicular to the major axis of bending. This point is discussed more fully in Chapter 10 of the book.

\section{Solution to Exercise 4.2}

Minimum 18 in. square; floor-floor $=12$ feet, $1 / d=12$ inches, calculated 12 inches square; 5 stories add 5 in. to 17 in. square. Use minimum of 18 in. $\times 18$ in.

The actual sizes are First floor 20 in. $\times 20$ in., upper floors 18 in. $\times 18$ in.

\section{Solution to Exercise 4.3}

Calculation by Table S4.2.

Ground floor $675 \mathrm{~mm} \times 675 \mathrm{~mm}$

Second Floor $650 \mathrm{~mm} \times 650 \mathrm{~mm}$

Fourth Floor $600 \mathrm{~mm} \times 600 \mathrm{~mm}$

Sixth Floor $525 \mathrm{~mm} \times 525 \mathrm{~mm}$

Ninth Floor and above $450 \mathrm{~mm} \times 450 \mathrm{~mm}$

The actual sizes of the interior columns in this project

Ground floor $700 \mathrm{~mm} \times 700 \mathrm{~mm}$

Second floor $600 \mathrm{~mm} \times 600 \mathrm{~mm}$

Fourth Floor $650 \mathrm{~mm} \phi$ (equivalent area to $575 \mathrm{~mm} \times 575 \mathrm{~mm}$ )

Sixth Floor $650 \mathrm{~mm} \phi$

Eighth Floor and above $550 \mathrm{~mm} \phi$ (equivalent area to $500 \mathrm{~mm} \times 500 \mathrm{~mm}$ )

Note: This building has unusually heavy floor loads

\section{Solution to Exercise 4.4}

Use $\mathrm{L} / \mathrm{d}=25,178 \mathrm{in} / 25=7$ inches, minimum $=4$ in. +2 in. $=6$ in.. Use 7 in. square. [Actual 6 in. $\times 8$ in.]

\section{Solution to Exercise 4.5}

a) I-beam, ground floor, use $1 / \mathrm{d}$ ratios (no increase necessary for four floors, but use lesser $1 / \mathrm{d}$ ratio, say 20-30. Use $200 \mathrm{~mm}$ column for full height of building,

UC $203 \times 203 \times 100\left(\mathrm{~A}=127 \mathrm{~cm}^{2}\right)$

b) Supplementary exercise; design by Rankine-Gordon formula Total load $=6.5 \mathrm{kN} / \mathrm{m}^{2} \times 72 \mathrm{~m}^{2} \times 4$ floors $=1870 \mathrm{kN}$.

Use steel allowable stress of $\mathrm{a}=200 \mathrm{~N} / \mathrm{mm}^{2}$, which is placed in the numerator of the Rankine-Gordon formula.

The reduction by the Rankine Gordon formula $=\left(1+\left(\mathrm{L}^{2} / \mathrm{cd}^{2}\right)\right)^{-1}$

Using $\mathrm{L} / \mathrm{d}=20$

$=\left(1+20^{2} / 1200\right)^{-1}=0.75$,

allowable stress $=150 \mathrm{~N} / \mathrm{mm}^{2}$ 
actual stress $=1870 \mathrm{kN} / 12700 \mathrm{~mm}^{2}=147 \mathrm{~N} / \mathrm{mm}^{2}$.

Note: Blue Book Compression resistance value (loads factored) $=2480 \mathrm{kN}$;

\section{Solution to Exercise 4.6}

Solution: weak axis is braced by sheathing (plywood exterior and gypsum wallboard interior). For strong direction L/d of less than 30 , preferably 20 , is required. Thus, maximum height of a $2 \times 4$ column is 3.5 in $\times 30$ $=105$ in $(8 \mathrm{ft} .9 \mathrm{in}$. $)$; or for a $2 \times 6=5.5 \times 30=165$ in $(13 \mathrm{ft}$. $9 \mathrm{in}$. $)$, so 8 foot wall, use $2 \times 4,10$ foot and 12 foot wall, use $2 \times 6$.

\section{Solution to Exercise 4.7}

\section{US}

Table 4.2 shows that the strong axis $\mathrm{L} / \mathrm{d}$ is in the range of $25-35$, while the weak axis range is $12-20$. The column should be oriented so that it is supported about the weak axis at both floors (see Figure E4.5). The size of the column is 120 inches/15 or 240 inches/30, approximately, or 8 inches.

\section{UK}

Table 5-2 shows that the strong axis $\mathrm{L} / \mathrm{d}$ is in the range of $25-35$, while the weak axis range is $12-20$. The column should be oriented so that it is supported about the weak axis at both floors (see Figure E4.5). The size of the column is $3250 \mathrm{~mm} / 15$ or $6500 \mathrm{~mm} / 30$, approximately, or $203 \mathrm{~mm}$.

\section{Solution to Exercise 4.8}

\section{US}

Unsupported height $/$ width $=12$. Use 16 inch square piers (either pilaster block or built up from 8 in. $\times 16$ in. nominal units.

\section{UK}

Unsupported height $/$ width $=12$. Use $440 \mathrm{~mm} \times 360 \mathrm{~mm}$ piers (use $3440 \times 120$ wide in each layer)

\section{Solution to Exercise 4.9}

\section{US}

Concrete column size is minimum 13 in +1 in per floor, overall minimum 18 in. $\times 18$ in., that is 18 in. $\times 18$ in.. Steel column size is $13 \mathrm{feet} / 20=8$ in $\times 8$ in.

Concrete floor area used is $(1.5 \mathrm{ft})(1.5 \mathrm{ft}) /(28 \mathrm{ft})(28 \mathrm{ft})=0.3 \%$

Steel floor area used is $(0.67 \mathrm{ft})(0.67 \mathrm{ft}) /(28 \mathrm{ft})(28 \mathrm{ft})=0.05 \%$ 


\section{UK}

Concrete column size is minimum $330 \mathrm{~mm}+25$ per floor, overall minimum $450 \mathrm{~mm} \times 450 \mathrm{~mm}$, that is $450 \mathrm{~mm}$ $\times 450 \mathrm{~mm}$. Steel column size is $4 \mathrm{~m} / 20=200 \mathrm{~mm} \times 200 \mathrm{~mm}$

Concrete floor area used is $(0.45 \mathrm{~m})(0.45 \mathrm{~m}) /(8 \mathrm{~m})(8 \mathrm{~m})=0.3 \%$

Steel floor area used is $(0.20 \mathrm{~m})(0.20 \mathrm{~m}) /(8 \mathrm{~m})(8 \mathrm{~m})=0.06 \%$ 
Supplementary Material for Chapter 5: Solutions and Supplementary Exercises

Solutions to Chapter 5 Exercises

Solution to Exercise 5.1

Answer: $2 \times 10,2 \times 12,2 \times 14$

Solution to Exercise 5.2(US)

\begin{tabular}{lllll}
\hline Span & Dimension lumber & span:depth & GP I & span/depth \\
\hline 12 & $2 \times 10$ HF No.2 & 15.6 & GPI 20 9.5 & 15.1 \\
14 & $2 \times 12$ HF No. 2 & 14.9 & GPI 40 9.5 & 17.7 \\
16 & $2 \times 12$ HF No.1\& Btr. & 17.0 & GPI 65 11.875 & 16.1 \\
18 & none & none & GPI 65 11.875 & 18.1 \\
\hline
\end{tabular}

Solution to Exercise 5.2(Canada)

\begin{tabular}{lllll}
\hline $\begin{array}{l}\text { Span (max. } \\
\text { moment) }\end{array}$ & Dimension lumber & span:depth & Metsawood & span/depth \\
\hline $3.5(3.5 \mathrm{kNm})$ & $38 \times 235 \mathrm{~S}-\mathrm{P}-\mathrm{F}$ & 14.9 & $160-38-36$ & 22 \\
$4.0(4.5 \mathrm{kNm})$ & $38 \times 235 \mathrm{~S}-\mathrm{P}-\mathrm{F}$ & 17.0 & $200-38-36$ & 20 \\
$4.5(5.8 \mathrm{kNm})$ & $38 \times 286 \mathrm{DF}-\mathrm{L}$ & 15.8 & $200-38-36$ & 22.5 \\
5.0 & none & none & $220-45-36$ & 22.7 \\
\hline
\end{tabular}

Solution to Exercise 5.3

See Figure S5.1

Figure S5.1

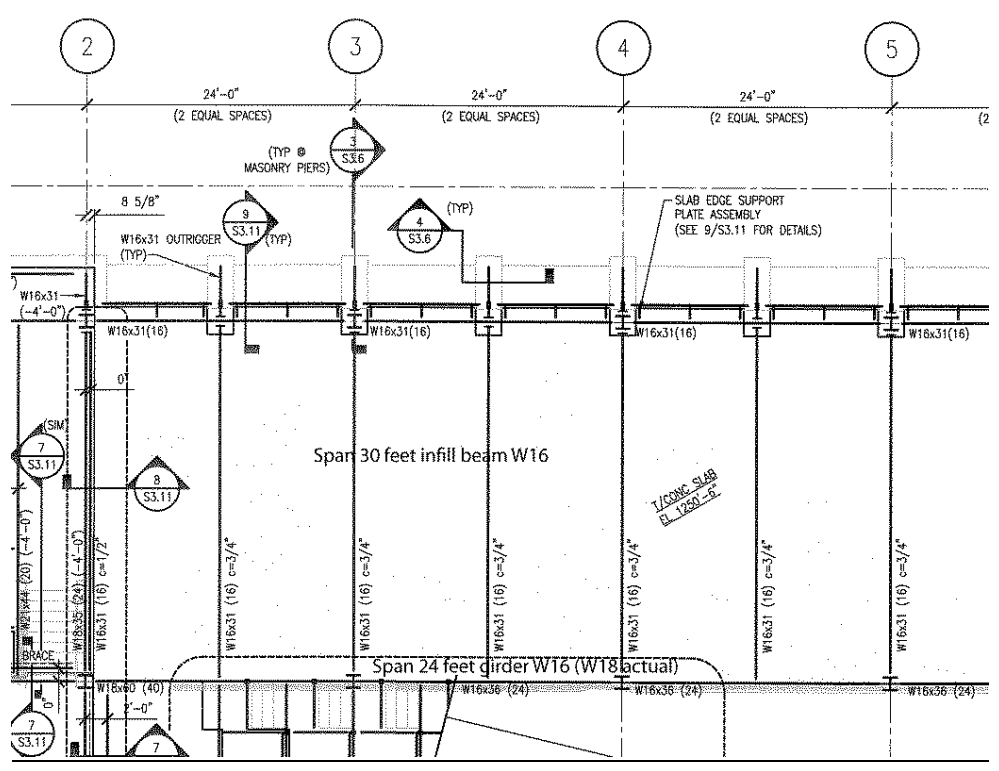


Solution to Exercise 5.4

See Figure S5.2

Figure S5.2. (a) Solution to Exercise 5.4 using dimension lumber
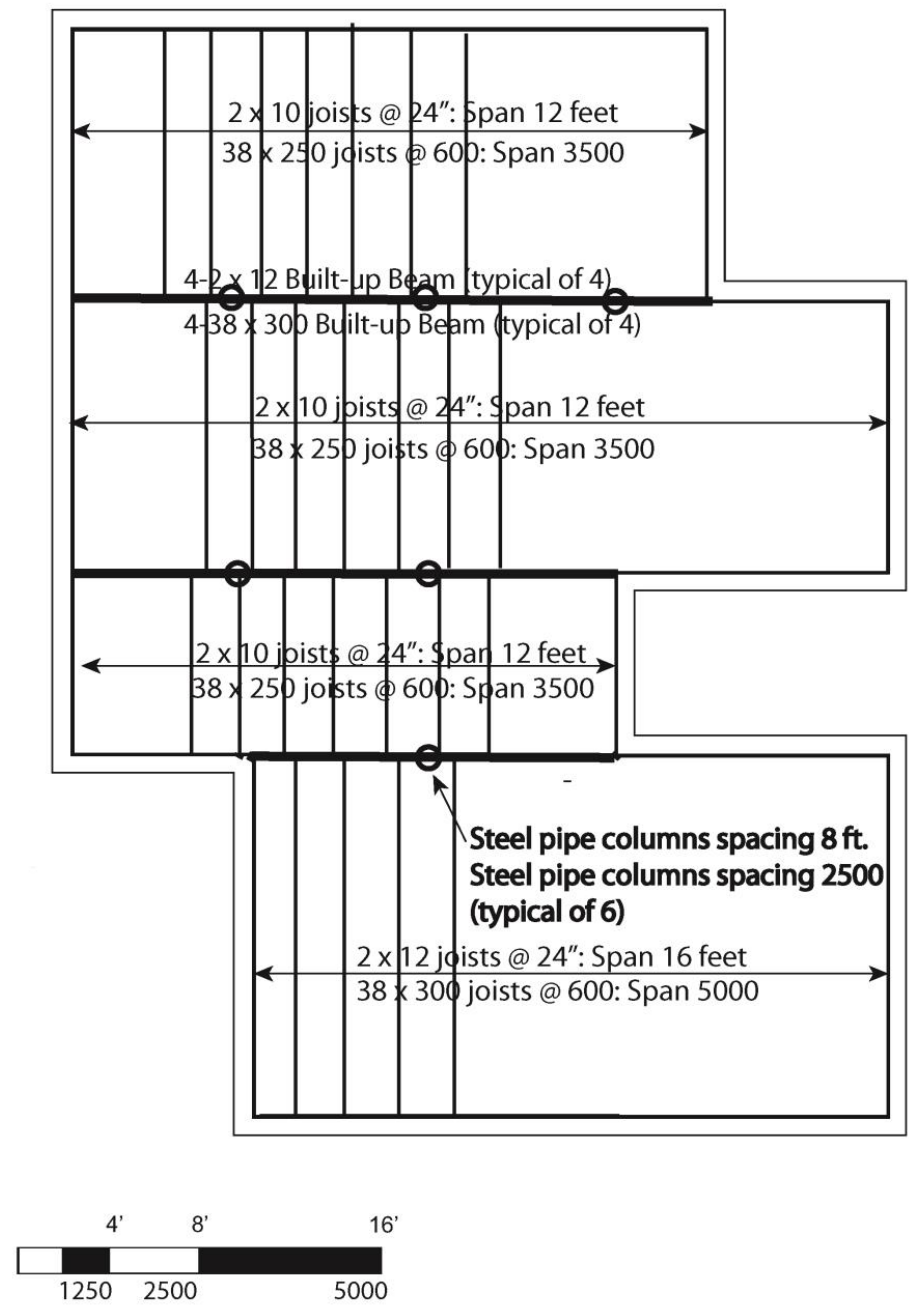

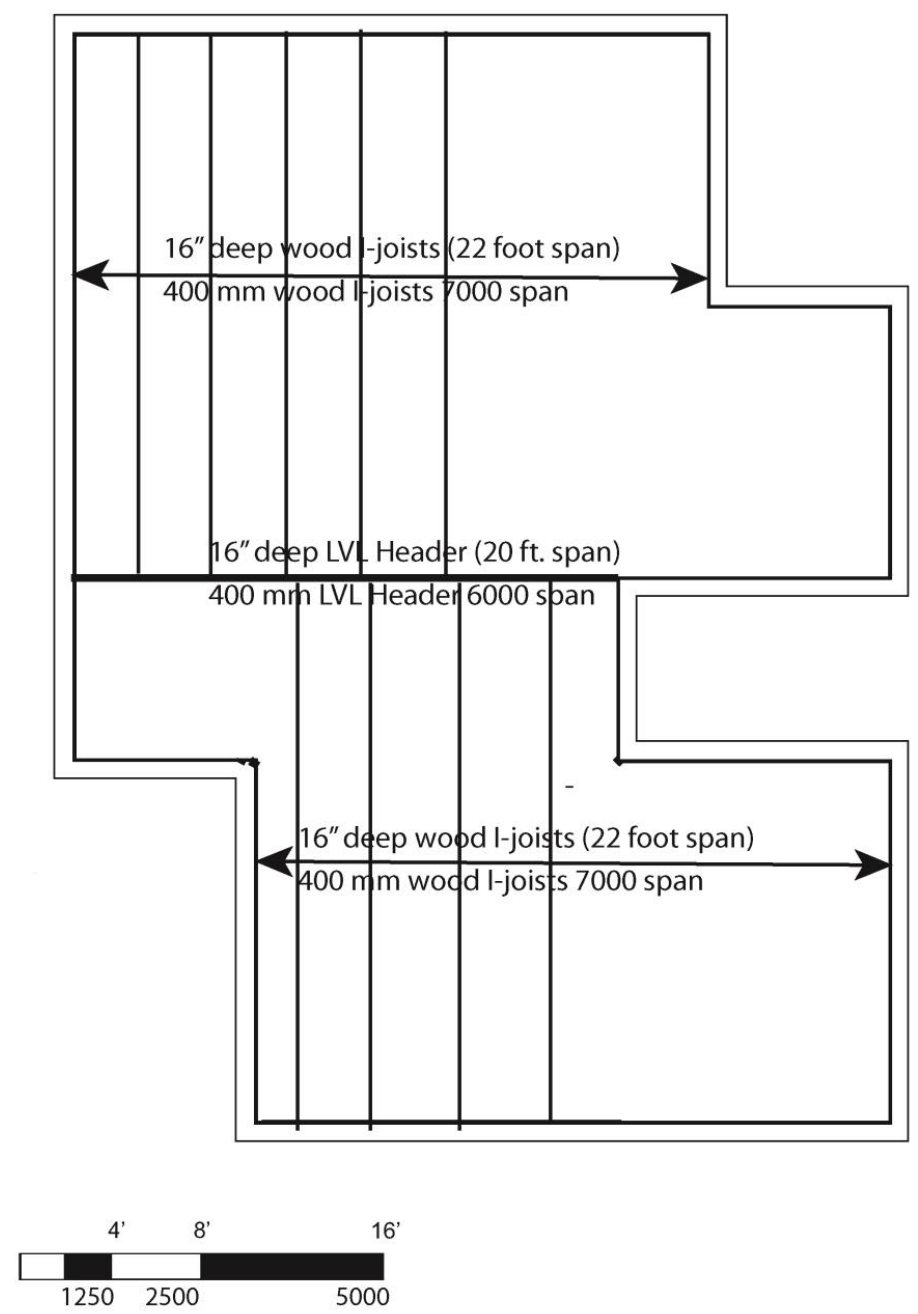

\section{Solution to Exercise 5-5}

\section{US}

32 foot infill beam span direction, use 4 infill beam spaces, W16 $\times 26$; girder size $\mathrm{W} 16 \times 35$ (based on L/20 girders, L/24 beams)

Total weight $=4(26)(32)+1(35)(28)=4308 \mathrm{lb}$

28 foot infill beam span direction, use 4 infill beam spaces $\mathrm{W} 16 \times 26$; girder size $\mathrm{W} 21 \times 55$

(based on $\mathrm{L} / 20$ )

Total weight $=4(26)(28)+1(55)(32)=4670 \mathrm{lb}$

Spanning girders in shorter direction is usually more economical than the alternative. 


\section{UK}

$10000 \mathrm{~mm}$ infill beam span direction, use 4 infill beam spaces, UB457 × $152 \times 52$; girder size $457 \times 152 \times 67$ (based on $\mathrm{L} / 20$ )

Total weight $=4(10)(52)+1(8.5)(67)=2650 \mathrm{~kg}$

28 foot infill beam span direction, use 4 infill beam spaces UB457 $\times 152 \times 52$; girder size UB533 $\times 165 \times 66$ (based on $\mathrm{L} / 20$ )

Total weight $=4(8.5)(52)+1(10)(66)=2430 \mathrm{~kg}$. Although this scheme results in slightly lesser steel weight, the depths are different between infill beams and girders.

Spanning girders in shorter direction is usually preferable to the alternative.

\section{Solution to Exercise 5.6}

Precast, prestressed double tees span 60 feet in the longer direction (vertically on page). Span/depth ratio 24 . Depth $=60 \mathrm{ft} . \times 12$ in. $/ \mathrm{ft} . \div 24=30 \mathrm{in}$.

Inverted tee girders span in perpendicular direction at interior column line. Span/depth ratio 12

Depth $=30 \mathrm{ft} . \times 12$ in. $/ \mathrm{ft} \div 12=30$ in.

Actual double tees and inverted tee girders $=34$ in.

\section{Solution to Exercise 5.7}

Bay size $6000 \mathrm{~mm} \times 10275 \mathrm{~mm}$

All bays exterior; span/depth ratio 30; depth $=10275 \mathrm{~mm} / 30=340 \mathrm{~mm}$.

(Note: Span/depth ratio may be applied to clear distance between columns, i.e. $9775 \mathrm{~mm} / 30=325 \mathrm{~mm}$

Actual $=325 \mathrm{~mm}$

\section{Solution to Exercise 5.8}

\section{US}

Solution: Joists (ribs) span long way, girders short way. Joist depth (continuous both sides) $=30$ feet $/ 21=18$ inches. Girder depth $=18$ inches. Slab depth $=4.5$ inches normal weight concrete (span/16), primarily based on fire resistance requirements.

\section{UK}

Solution: Joists (ribs) span long way, girders short way. Joist depth (continuous both sides) $=9000 \mathrm{~mm} / 21=$ $450 \mathrm{~mm}$. Girder depth $=450 \mathrm{~mm}$. Slab depth $=115 \mathrm{~mm}$ normal weight concrete $(\mathrm{span} / 14)$, primarily based on fire resistance requirements. 


\section{Supplementary Exercises Chapter 5}

\section{Exercise S5.1}

Figure S5.3 shows a partial steel framing plan from a steel framed University educational building in the UK. Construction consists of $250 \mathrm{~mm}$ precast prestressed hollow-core plank, primarily supported by asymmetric steel beams. The plank span is indicated by the double arrows on the plan. ASB steel beams are used to facilitate the placement of the concrete plank.

Choose sizes for the beams shown in the circled area of the plan. Table S5-1 shows the sizes of ASB (Asymmetric Steel Beams) available in the UK.

It is important to understand in this case that the depth of the asymmetric beams that support the precast plank is limited to approximately $300 \mathrm{~mm}$, because this is the depth of the plank that these beams are supporting. As a result, significantly heavier sections are used than would be the normal practice for steel beams and an apparent span/depth rule of 24 is used, even for the girders supporting the precast plank.

\section{Solution to Exercise S5.1}

The load path is generally hollow concrete plank floor to beams to columns. The beams running parallel to the span direction of the concrete plank are carrying only nominal loads, and can be proportioned as infill beams (span:depth 24 or more) and the perpendicular beams are proportioned as girders (span:depth 24). In some cases, the beams are cantilevered, calling for a span: depth ratio of 10 or less for the cantilevered segment.

Beam mark RFB1, maximum span e-w 7967 (infill), required depth $331 \mathrm{~mm}$ or less

Beam mark RFB1, maximum span n-s 6600 (girder), required depth $276 \mathrm{~mm}$

Beam mark RFB4, maximum span e-w 3377 (cantilever), required depth $338 \mathrm{~mm}$

Beam mark RFB 3, maximum span e-w 6600 (girder), required depth $278 \mathrm{~mm}$

Beam mark RFB 5, maximum span n-s 3120 (cantilever), required depth $312 \mathrm{~mm}$

The beam selections based on the above considerations are given below, along with the actual beams used in this project. (note that Beam RFB 4 supports other beams, and an ASB is not required.

\begin{tabular}{|c|c|c|c|}
\hline \multirow[t]{4}{*}{ Beam mark } & RFB1 & 300ASB 155 & 300 ASB 155 \\
\hline & RFB3 & 300 ASB 155 & 280 ASB 100 \\
\hline & RFB4 & 300 ASB 196 & $210 \times 267 \times 46$ Tee \\
\hline & RFB5 & UC $356 \times 368 \times 129$ & $\mathrm{UC} 356 \times 368 \times 129$ \\
\hline
\end{tabular}

\section{Exercise S5.2}

The small storage building depicted in Figure S5.4 has rigid frames spanning 12 meters, and spaced 6 meters apart. Secondary members consisting of $200 \mathrm{~mm} \mathrm{Z}$ purlins are spaced 1.5 meters and span from frame to frame. Find the approximate size of the beams and columns of the frame.

\section{Solution to Exercise S5.2}

Beams: continuous both sides, spanning 12 meters. $12000 \mathrm{~mm} / 30=400 \mathrm{~mm}$.

Columns: $200 \mathrm{~mm}$ minimum, subjected to same bending moment, $400 \mathrm{~mm}$. 


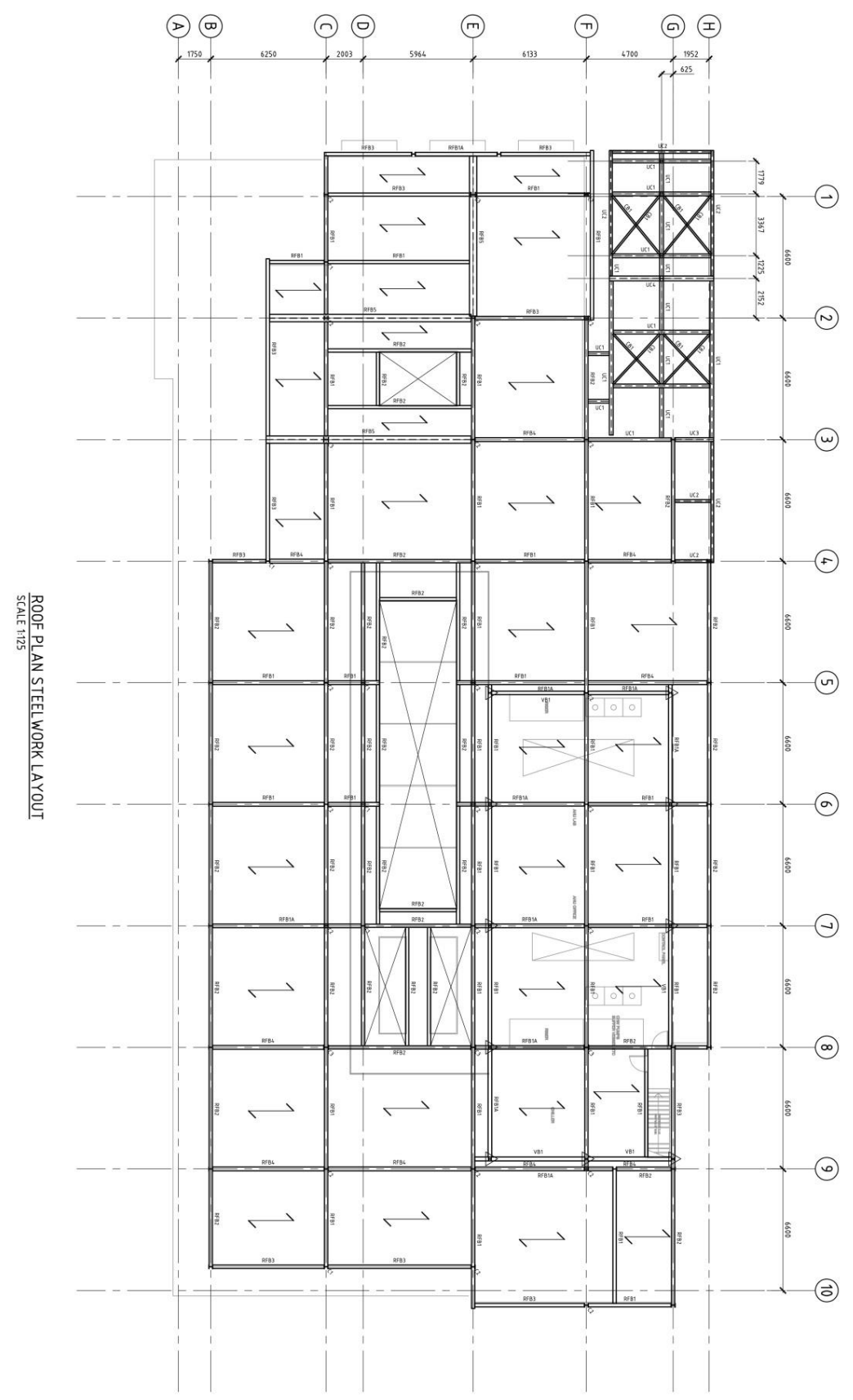


Table S5.1. Available Sizes of Asymmetric Steel Beams (ASB)

\begin{tabular}{|c|c|c|c|c|c|c|c|c|c|}
\hline \multirow[t]{4}{*}{ No } & \multirow{4}{*}{$\begin{array}{l}\text { Section } \\
\text { Designation }\end{array}$} & \multirow{2}{*}{$\begin{array}{l}\text { Mass } \\
\text { per } \\
\text { Metre } \\
\end{array}$} & \multirow{2}{*}{$\begin{array}{l}\text { Depth } \\
\text { of } \\
\text { Section }\end{array}$} & \multicolumn{2}{|c|}{ Width of Flange } & \multicolumn{2}{|c|}{ Thickness of } & \multirow{2}{*}{$\begin{array}{l}\text { Root } \\
\text { Radius }\end{array}$} & \multirow{2}{*}{$\begin{array}{l}\text { Depth } \\
\text { between } \\
\text { Fillets }\end{array}$} \\
\hline & & & & Top & Bottom & Web & Flange & & \\
\hline & & $\mathrm{M}$ & $\mathrm{H}$ & $b_{t}$ & $b_{b}$ & $t_{w}$ & $t_{f}$ & $r$ & $\mathrm{~d}$ \\
\hline & & $\mathrm{kg} / \mathrm{m}$ & $\mathrm{mm}$ & $\mathrm{mm}$ & $\mathrm{mm}$ & $\mathrm{mm}$ & $\mathrm{mm}$ & $\mathrm{mm}$ & $\mathrm{mm}$ \\
\hline 1 & 300 ASB 249 & 249 & 342 & 203 & 313 & 40.0 & 40.0 & 27.0 & 208 \\
\hline 2 & 300 ASB 196 & 196 & 342 & 183 & 293 & 20.0 & 40.0 & 27.0 & 208 \\
\hline 3 & 300 ASB 185 & 185 & 320 & 195 & 305 & 32.0 & 29.0 & 27.0 & 208 \\
\hline 4 & 300 ASB 155 & 155 & 326 & 179 & 289 & 16.0 & 32.0 & 27.0 & 208 \\
\hline 5 & 300 ASB 153 & 153 & 310 & 190 & 300 & 27.0 & 24.0 & 27.0 & 208 \\
\hline 6 & 280 ASB 136 & 136 & 288 & 190 & 300 & 25.0 & 22.0 & 24.0 & 196 \\
\hline 7 & 280 ASB 124 & 124 & 296 & 178 & 288 & 13.0 & 26.0 & 24.0 & 196 \\
\hline 8 & 280 ASB 105 & 105 & 288 & 176 & 286 & 11.0 & 22.0 & 24.0 & 196 \\
\hline 9 & 280 ASB 100 & 100 & 276 & 184 & 294 & 19.0 & 16.0 & 24.0 & 196 \\
\hline 10 & 280 ASB 74 & 73.6 & 272 & 175 & 285 & 10.0 & 14.0 & 24.0 & 196 \\
\hline
\end{tabular}

Figure S5.4. Small Preengineered Storage Building. Courtesy General Steel https://gensteel.com/steel_building-kits/storage

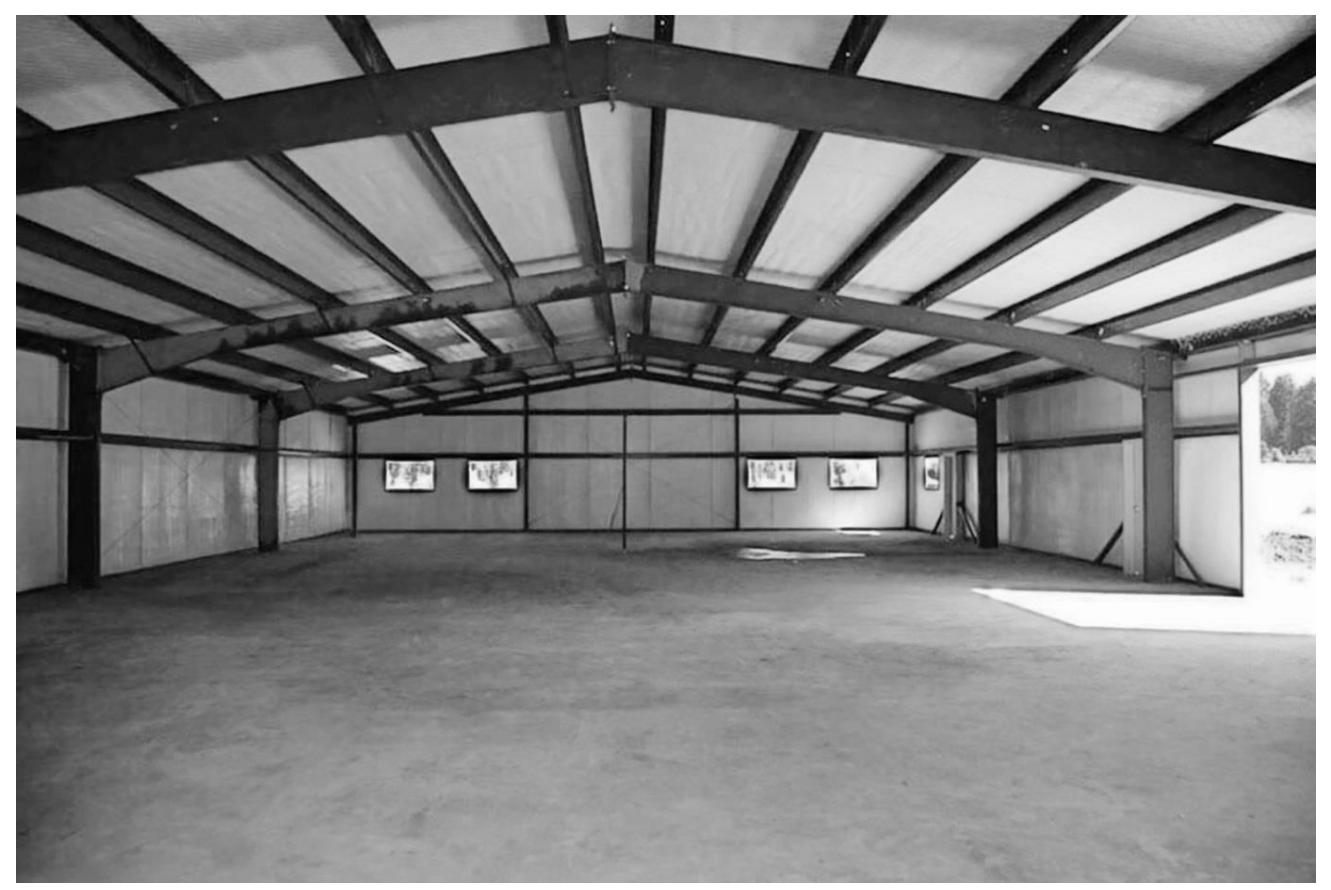




\title{
Supplementary Material for Chapter 6
}

\section{Solutions to Chapter 6 Exercises}

\author{
Solution to Exercise 6.1.
}

\section{US}

Span/depth ratio 12, measured at midspan. Midspan depth $=3.33$ feet.

Roof pitch $=3.33 \mathrm{ft} / 20 \mathrm{ft}=2: 12$.

\section{UK}

Span/depth ratio 12, measured at midspan. Midspan depth $=1000 \mathrm{~mm}$.

Roof pitch $=1000 \mathrm{~mm} / 6000 \mathrm{~mm}=10^{\circ}$

\section{Solution to Exercise 6.2}

\section{US}

Per Exercise 6.1, minimum midspan depth $=3.33 \mathrm{ft}$. Additional $1.33 \mathrm{ft}$. of rise required in $20 \mathrm{ft}$. Top chord pitch $=1.33 \mathrm{ft} / 20 \mathrm{ft}=1 / 12$.

\section{UK}

Per Exercise 6.1, minimum midspan depth $=1000 \mathrm{~mm}$. Additional $400 \mathrm{~mm}$ of rise required in $6000 \mathrm{~mm}$.

Top chord pitch $=400 \mathrm{~mm} / 6000 \mathrm{~mm}=5^{\circ}$.

\section{Solution to Exercise 6.3}

\section{US}

Midspan depth $=84 \mathrm{ft} / 12=7 \mathrm{ft}$. Top chord pitch $=5 \mathrm{ft} / 42 \mathrm{ft}=2 / 12$

Actual midspan depth $=2 \mathrm{ft}+2 / 12 \times 42 \mathrm{ft}=9 \mathrm{ft}$.

Try $6 \mathrm{ft}$ panels; required top chord depth $=72 \mathrm{in} / 10$ (see correction to Table 6.3 ) use $2 \times 8$ top chord Bottom chord depth $=72$ in $/ 12$ use $2 \times 6$ bottom chord

Web member depth $=72$ in/15 use $2 \times 6$ web members

\section{UK}

Midspan depth $=26000 \mathrm{~mm} / 12=2200 \mathrm{~mm}$. Top chord pitch $=1600 \mathrm{~mm} / 13000 \mathrm{~mm}=8^{\circ}$

Try $2000 \mathrm{~mm}$ panels; required top chord depth $=2000 \mathrm{~mm} / 10$ (see correction to Table 6.3) use $38 \times 200$ top chord

Bottom chord depth $=2000 \mathrm{~mm} / 12$ use $38 \times 175$ bottom chord 


\section{Solution to Exercise 6.4 .}

See Figure S6.1

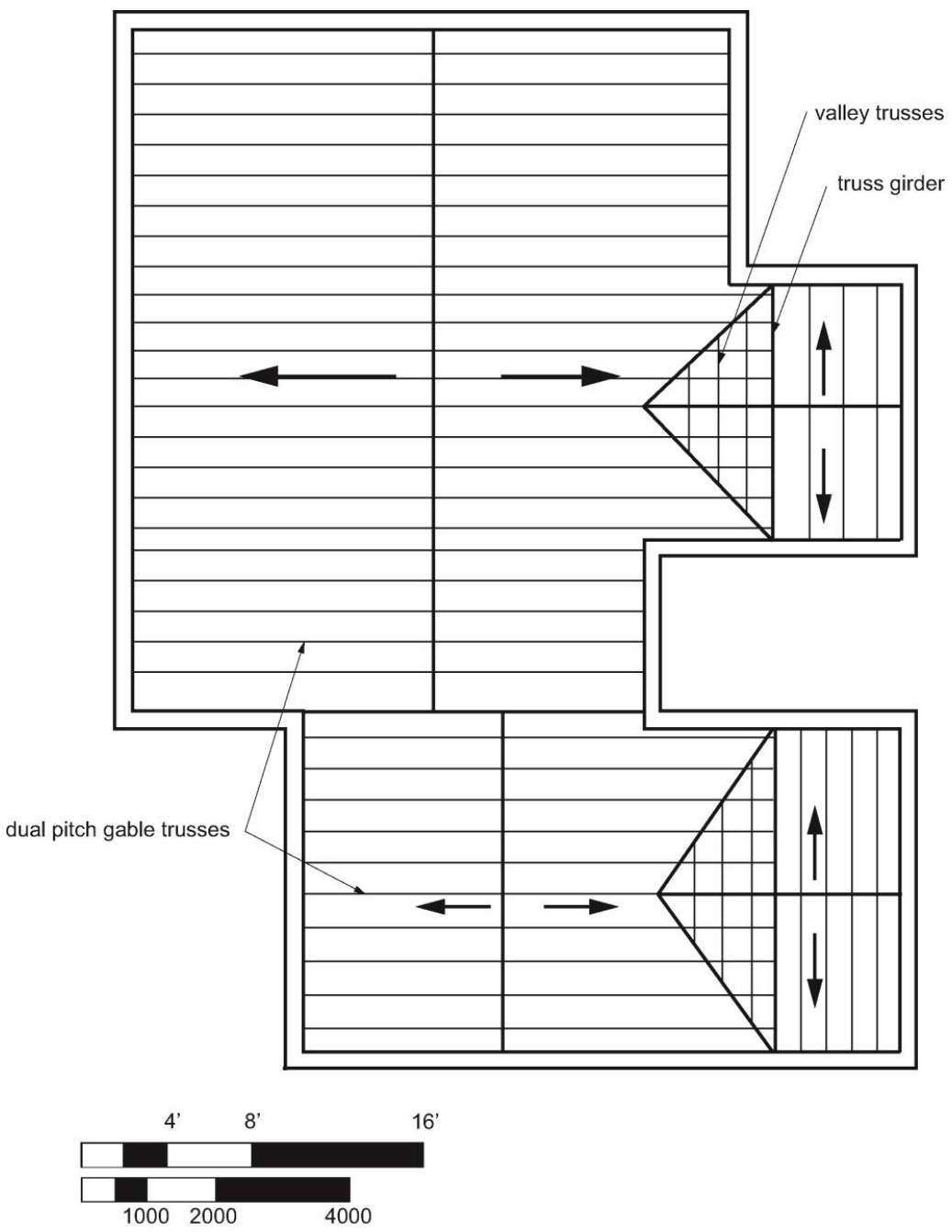

\section{Solution to Exercise 6.5}

a) Use span/depth ratio of 15 , depth 8 feet. Top chord pitch $1 / 2$ to $1: 12$

b) Use minimum roof pitch $4: 12$, midspan depth $=20$ feet. Top chord pitch $4: 12$

Truss spacing 8 feet- 12 feet, steel purlins 6 in.- 8 in. deep approximately span between, in addition to some form of bottom chord bracing. 


\section{Supplementary Material for Chapter 7}

\section{Supplementary Exercises}

\section{Exercise S7.1}

\section{US}

Six story office building with footprint of $140 \times 200$ feet. Choose bay size and member size for steel framing.

\section{UK}

Six story office building with footprint $40000 \mathrm{~mm} \times 64000 \mathrm{~mm}$. Choose bay size and member size for steel framing

\section{Solution to Exercise S7.1}

\section{US}

Bay size 35 feet $\times 25$ feet ( 4 bays $\times 8$ bays)

Infill beam size $=35$ feet $/ 24=18$ inches

Girder size $=25$ feet $/ 20=16$ inches, say 18 inches

Column size W12

\section{UK}

Bay size $10000 \mathrm{~mm} \times 8000 \mathrm{~mm}(4$ bays $\times 8$ bays $)$

Infill beam size $=10000 \mathrm{~mm} / 24=450 \mathrm{~mm}$

Girder size $=8000 \mathrm{~mm} / 20=400 \mathrm{~mm}$, say $450 \mathrm{~mm}$

Column size UC 305

\section{Exercise 7.2.}

\section{US}

Posttensioned Concrete floor system for Office building $140 \mathrm{ft} \times 200 \mathrm{ft}$

\section{UK}

Posttensioned Concrete floor system for Office building $40000 \mathrm{~mm} \times 60000 \mathrm{~mm}$. 


\section{Solution to Exercise 7.2}

\section{US}

Bay size 20 feet $\times 40 \mathrm{ft}$.

$\mathrm{p} / \mathrm{t}$ slab, 20 foot span $/ 40=6$ inches

$\mathrm{p} / \mathrm{t}$ girders 40 foot $\mathrm{span} / 30=1.33 \mathrm{ft}$, say $16 \mathrm{in}$.

\section{UK}

Bay size $6000 \mathrm{~mm} \times 13300 \mathrm{~mm}$

$\mathrm{p} / \mathrm{t} \mathrm{slab}, 6000 \mathrm{~mm} / 40=150 \mathrm{~mm}$

$\mathrm{p} / \mathrm{t}$ girders $13300 \mathrm{span} / 30=450 \mathrm{~mm}$ 


\title{
Supplementary Material for Chapter 8
}

\section{Solution to Exercise 8.1}

For an interior column, a load estimate of $13440 \mathrm{kN}$ has already been determined. Required footing area $=$ $13440 \mathrm{kN} / 250 \mathrm{kN} / \mathrm{m}^{2}=54 \mathrm{~m}^{2}=7.5 \mathrm{~m} \times 7.5 \mathrm{~m}$. Since this is approximately the size of a single bay, it is infeasible to use a spread footing foundation. On the other hand a mat foundation, effectively a single spread footing, could well be considered. The thickness of the mat would be approximately one meter.

\section{Solution to Exercise 8.2}

Solution according to Table 8.4

\section{US}

10 foot fill height, cut section, 8 foot footing width, Wall thickness $=1.25$ feet, 15 in.

footing thickness $=8$ feet $/ 8=12$ in.

Fill section, 7 foot footing width, all other values remain the same.

\section{UK}

$3000 \mathrm{~mm}$ fill height, cut section, $2100 \mathrm{~mm}$ footing width,

Wall thickness $=400 \mathrm{~mm}$.

footing thickness $=3000 \mathrm{~mm} / 8=375 \mathrm{~mm}$.

Fill section, 1800 footing width, all other values remain the same.

\section{Solution to Exercise 8.3}

Maximum wall load $=15$ feet $\times 50 \mathrm{lbs} / \mathrm{ft}^{2} \times 3$ floors $=2500 \mathrm{lb} / \mathrm{ft}$

minimum footing width $=18$ inches.

footing width required by loads $=2500 \mathrm{lb} / \mathrm{ft} \div 2000 \mathrm{lbs} / \mathrm{ft}^{2}=1.25$ feet.

Use 18 inch wall footing

\section{Solution to Exercise 8.4}

US

\author{
floor load $=50 \mathrm{lb} / \mathrm{ft}^{2}$ live load $+20 \mathrm{lb} / \mathrm{ft}^{2}$ dead load $=70 \mathrm{lb} / \mathrm{ft}^{2}$ \\ roof load $=40 \mathrm{lb} / \mathrm{ft}^{2}$ \\ Wall load \\ from floor $=70 \mathrm{lb} / \mathrm{ft}^{2} \times 30 \mathrm{ft} / 2=1050 \mathrm{lb} / \mathrm{ft}$ \\ from roof $=40 \mathrm{lb} / \mathrm{ft}^{2} \times 30 \mathrm{ft} / 2=600 \mathrm{lb} / \mathrm{ft}$ \\ from wall $=40 \mathrm{lb} / \mathrm{ft}^{2} \times 25$ foot height $=1000 \mathrm{lb} / \mathrm{ft}$ \\ total $=2650 \mathrm{lb} / \mathrm{ft}$ \\ Column load \\ from floor $70 \mathrm{lb} / \mathrm{ft}^{2} \times 900 \mathrm{ft}^{2}=63000 \mathrm{lb}$ \\ from roof $40 \mathrm{lb} / \mathrm{ft}^{2} \times 900 \mathrm{ft}^{2}=36000 \mathrm{lb}$ \\ total $=99,000 \mathrm{lb}$
}


required area of column footing $=99,000 \mathrm{lb} \div 2000 \mathrm{lb} / \mathrm{ft}^{2}=45 \mathrm{ft}^{2}$

required width of wall footing $=2650 \mathrm{lb} / \mathrm{ft} \div 2000 \mathrm{lb} / \mathrm{ft}^{2}=1.33 \mathrm{ft}$

Use 7 foot $\times 7$ foot column footing

Use 18 in. continuous wall footing

\section{UK}

Solution to Exercise 8-5

floor load $=2.5 \mathrm{kN} / \mathrm{m}^{2}$ live load $+1.0 \mathrm{kN} / \mathrm{m}^{2}$ dead load $=03.5 \mathrm{kN} / \mathrm{m}^{2}$

roof load $=2.0 \mathrm{kN} / \mathrm{m}^{2}$

Wall load

from floor $=0.35 \mathrm{kN} / \mathrm{m}^{2} \times 9 \mathrm{~m} / 2=15.8 \mathrm{kN} / \mathrm{m}$

from roof $2.0 \mathrm{kN} / \mathrm{m}^{2} \times 9 \mathrm{~m} / 2=9 \mathrm{kN} / \mathrm{m}$

from wall $=2 \mathrm{kN} / \mathrm{m}^{2} \times 8 \mathrm{~m}$ height $=16 \mathrm{kN} / \mathrm{m}$

total $=40 \mathrm{kN} / \mathrm{m}$

Column load

from floor $3.5 \mathrm{kN} / \mathrm{m}^{2} \times 81 \mathrm{~m}^{2}=284 \mathrm{kN}$

from roof $2.0 \mathrm{kN} / \mathrm{m}^{2} \times 81 \mathrm{~m}^{2}=162 \mathrm{kN}$

total $=450 \mathrm{kN}$

$=$

required area of column footing $=450 \mathrm{kN} \div 100 \mathrm{kN} / \mathrm{m}^{2}=4.5 \mathrm{~m}^{2}$ required width of wall footing $=40 \mathrm{kN} / \mathrm{m} \div 100 \mathrm{kN} / \mathrm{m}^{2}=0.25 \mathrm{~m}$

Use $2250 \mathrm{~mm} \times 2250 \mathrm{~mm}$ column footing

Use $500 \mathrm{~mm}$ continuous wall footing

\section{Solution to Exercise 8.5}

Load on isolated footing every 30 feet

$=30,000 \mathrm{lbs}$. Footing area $=30,000 \mathrm{lbs} \div 2500 \mathrm{lb} / \mathrm{ft}^{2}=12 \mathrm{ft}^{2}$

Use $3.5 \mathrm{ft}$. $\times 3.5 \mathrm{ft}$. footing

Grade beam spans 30 feet, continuous both sides; minimum depth $=30$ feet $/ 18.5=1.62$ feet

Use 2 feet depth, unless frost conditions require a greater depth. 


\section{Supplementary Material for Chapter 9}

\section{Solution to Exercise 9.1}

See Figure S9.1

Figure S9.1

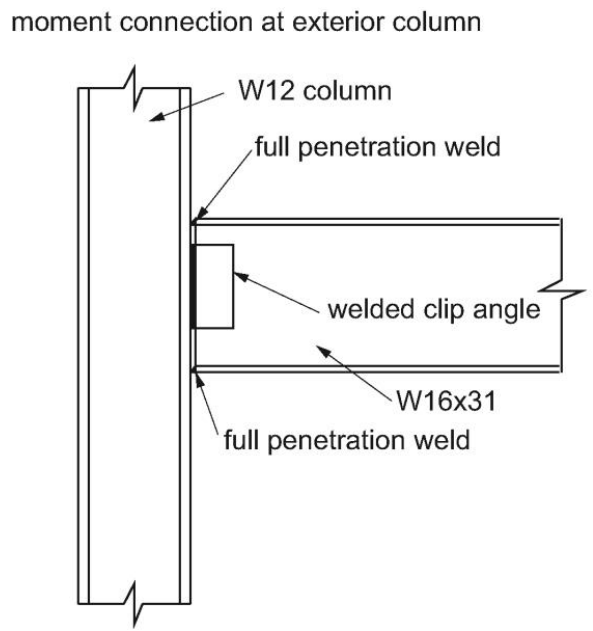

simple connection at interior column

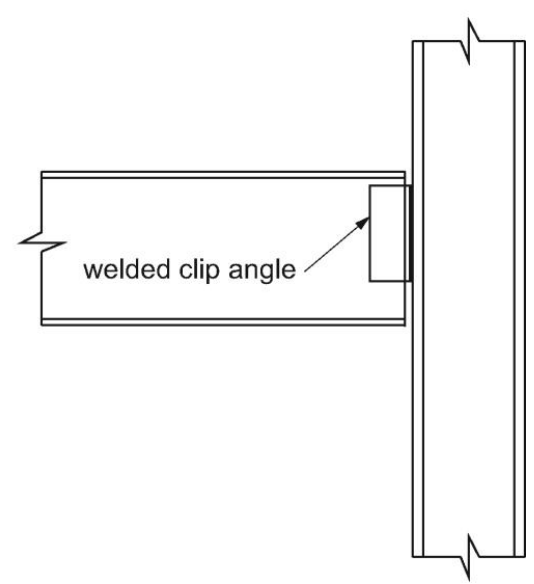

Solution to Exercise 9.2

See Figure S9.2

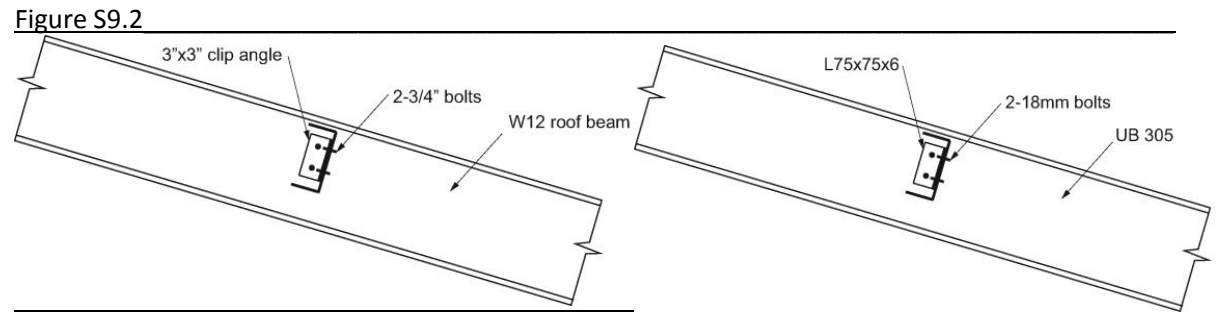

Solution to Exercise 9.3 (Correction: $3 \frac{1}{4}$ in. is a standard width for glu-lam)

See Figure S9.3

Figure S9.3 


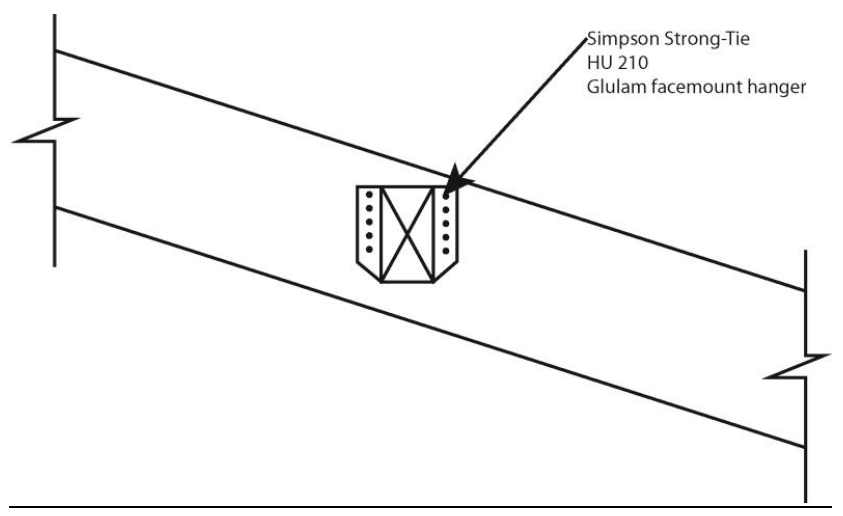

\section{Solution to Exercise 9.4}

Use Simpson Strong-Tie HHB $3 \frac{1}{4} \times 12$

\section{Solution to Exercise 9.5}

See Figure S9.4

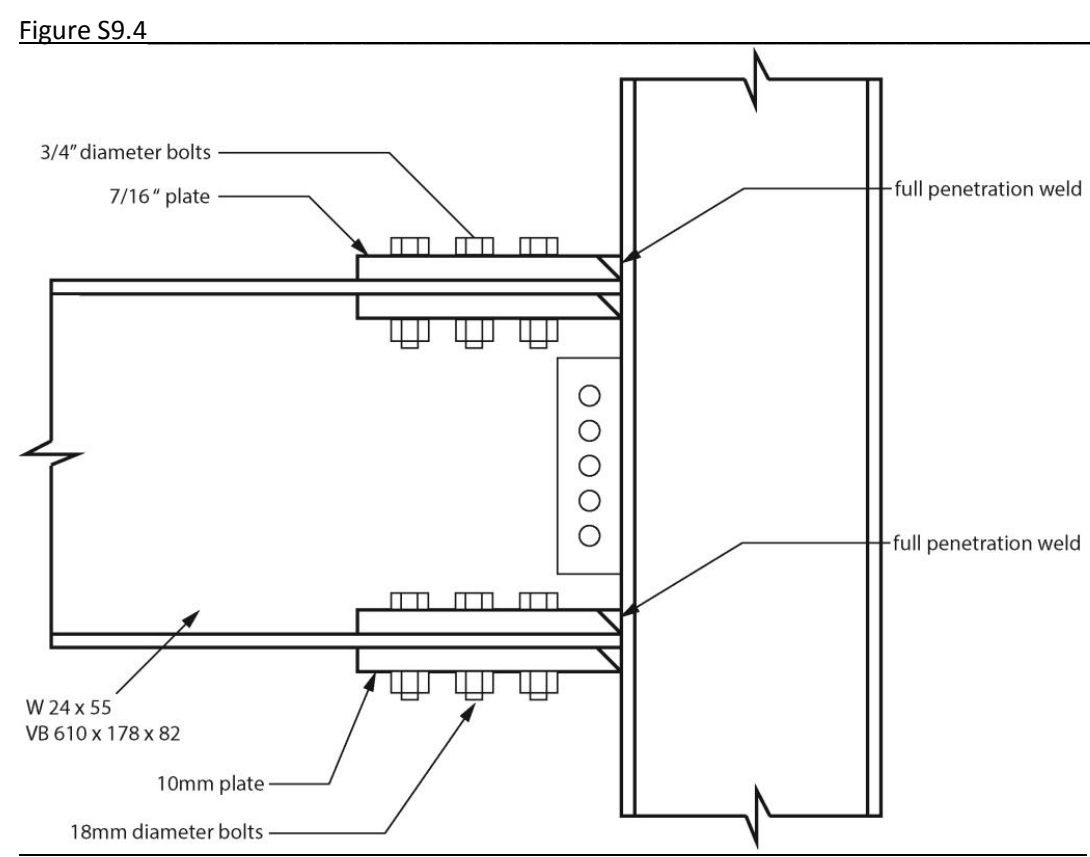

US

To complete this exercise, it is necessary to assume a size of W 24.

We will continue this exercise with a W24 $\times 55$.

Width of flange $=7.01 \mathrm{in}$; thickness of flange $=0.505 \mathrm{in}$. Area of flange $=3.54 \mathrm{in}^{2}$.

Use steel plates on top and bottom of each flange, combined thickness $=5 / 3 \times 0.505$ in $=0.841$ in.

Use $7 / 16$ in plates top and bottom. 
Use $3 / 4$ in. diameter bolts in two rows. Number of bolts per row $=5.5 \times .505=2.77$, say 3 bolts. Connection to column is by full penetration weld to plate.

Note: column requires an equivalent flange thickness. Use W12 × 53 (Flange thickness 0.575 in.)

In view of the difficulty of welding two plates at each flange, a single plate $7 / 8$ in. thick, with 6 bolts per row may be a better solution.

\section{UK}

To complete this exercise, it is necessary to assume a size of UB 610

We will continue this exercise with a UB $610 \times 178 \times 82$

Width of flange $=82 \mathrm{~mm}$; thickness of flange $=12.2 \mathrm{~mm}$. Area of flange $=10.0 \mathrm{~cm}^{2}$.

Use steel plates on top and bottom of each flange, combined thickness $=5 / 3 \times 12.2 \mathrm{~mm}=20.3 \mathrm{~mm}$.

Use $10 \mathrm{~mm}$ plates top and bottom.

Use $18 \mathrm{~mm}$ diameter bolts in two rows. Number of bolts per row $0.20 \times 10$, say 3 bolts per row

Connection to column is by full penetration weld to plate.

Note: column requires an equivalent flange thickness. Use UC $306 \times 306 \times 97$ (Flange thickness $=15.4 \mathrm{~mm}$ in.)

In view of the difficulty of welding two plates at each flange, a single plate $20 \mathrm{~mm}$ thick, with 6 bolts per row may be a better solution.

It is beyond the scope of this book, to locate a connection of this type in a seismic zone, except in the most general terms. It is necessary to make improvements to the connection. The type of weld of the flange plate can cause problems with brittle fracture. Stiffeners may have to be added to the column, and the beam is much stronger than the column, and the beam will have to be made to yield at a lower level of bending moments.

\section{Solution to Exercise 9.6}

See Figure S9.5

\section{US}

The flange width of the W18 $\times 35$ is 6 inches, while the clearance between flanges of the W12 $\times 79$ is $107 / 8$ in. No modifications to the beam web/column flange connection are necessary.

UK

The flange width of the UB $457 \times 152 \times 52$ is $152 \mathrm{~mm}$, while the clearance between flanges of the UC $305 \times 305 \times$ 118 is $277 \mathrm{~mm}$ No modifications to the beam web/column flange connection are necessary. 


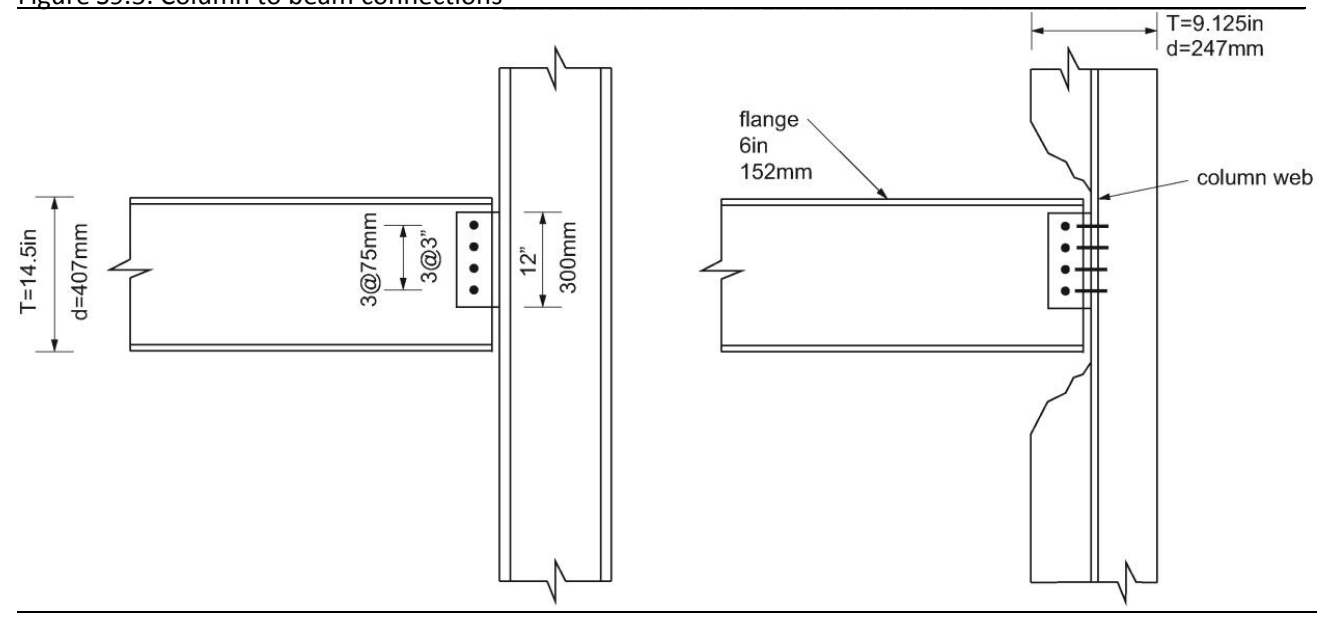

Solution to Exercise 9.7

See Figure S9.6

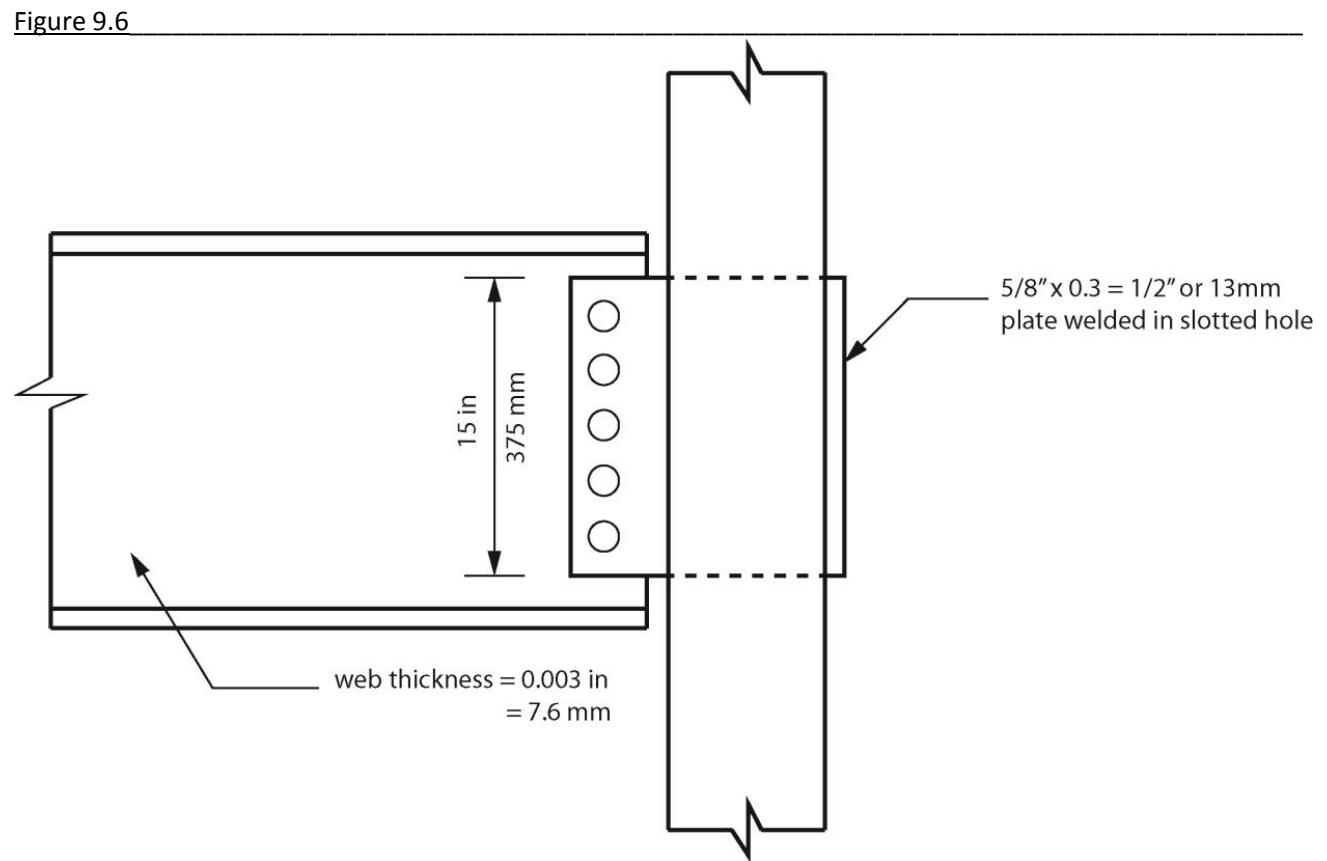




\title{
Supplementary Material for Chapter 10
}

\author{
Solution to Exercise 10.1
}

\section{US}

Lateral force applied to long side of building (length $=120$ feet). Loading is concentric, if shear walls are equally distributed

Required shear wall length

$100 \%$ for plywood $\times 3$ floors $=300 \%>200 \%$ minimum

$100 \%$ for oriented strand board (OSB) $\times 3$ floors $=300 \%>150 \%$ minimum

$200 \%$ for gypsum wallboard $\times 3$ floors $=600 \%>200 \%$ minimum

360 feet of transverse shear wall required for OSB or plywood, 720 feet of gypsum wallboard

Rule out gypsum wallboard in short direction

Available wall length $=26$ feet $\times 4$ walls +20 feet $\times 2$ walls per side of corridor $\times 2$ sides $=288$ feet.

Apply OSB or plywood to all interior and exterior walls at ground floor. Four interior walls require double plywood (one layer on each side) to double capacity Length of shear walls can be reduced proportionally at upper floors (i.e. 240 feet of shear wall required at second floor, 120 feet at third floor)

Lateral force applied to short side of building $=58$ feet

$300 \%$ of 58 feet for plywood $=174$ feet

$300 \%$ of 58 feet for OSB $=174$ feet

$600 \%$ of 58 feet for gypsum wallboard $=348$ feet

Available length $=2$ layers $\times 2$ sides $\times 120$ feet $=480$ feet

Use gypsum wallboard on all interior and exterior walls.

\section{UK}

Lateral force applied to long side of building (length $=36000 \mathrm{~mm}$ ). Loading is concentric, if shear walls are equally distributed.

Required shear wall length

$100 \%$ for plywood $\times 3$ floors $=300 \%>200 \%$ minimum

$100 \%$ for oriented strand board (OSB) $\times 3$ floors $=300 \%>150 \%$ minimum

$200 \%$ for gypsum wallboard $\times 3$ floors $=600 \%>200 \%$ minimum

$108 \mathrm{~m}$ of transverse shear wall required for OSB or plywood, $216 \mathrm{~m}$ of gypsum wallboard

Rule out gypsum wallboard in short direction

Available wall length $=8000 \mathrm{~mm} \times 4$ walls $+6000 \mathrm{~mm} \times 2$ walls per side of corridor $\times 2$ sides $=88 \mathrm{~m}$.

Apply OSB or plywood to all interior and exterior walls at ground floor. Four interior walls require double plywood (one layer on each side) to double their shear capacity. Length of shear walls can be reduced proportionally at upper floors (i.e. 72 meters of shear wall required at second floor, 36 meters at third floor)

Lateral force applied to short side of building $=18000 \mathrm{~mm}$

$300 \%$ of $18000 \mathrm{~mm}$ for plywood $=54000 \mathrm{~mm}$

$300 \%$ of $18000 \mathrm{~mm}$ for OSB $=54000 \mathrm{~mm}$

$600 \%$ of $18000 \mathrm{~mm}$ for gypsum wallboard $=108000 \mathrm{~mm}$

Available length $=2$ layers $\times 2$ sides $\times 36000 \mathrm{~mm}=144000 \mathrm{~mm}$

Use gypsum wallboard on all interior and exterior walls in long direction. 


\section{Solution to Exercise E10.2.}

Steel braced frame

4 storey one braced bay in each bay in each direction

8 storey two braced bays in each direction

12 storey two braced bays in each direction

Steel moment frame

4 storey at least $50 \%$ of exterior frames are moment frames

8 storey nearly all exterior moment frames are moment frames

12 storey all exterior frames are moment frames - consider additional shear walls at interior.

Reinforced Concrete shear wall

4 storey- $4 \times .05=20 \%$ of long wall dimension is required total length $=48$ feet $(14400 \mathrm{~mm})$

In long direction $150 / 240 \times 48$ feet required 30 feet $(9000 \mathrm{~mm})$

8 storey- $8 \times .05=40 \%$ of long wall dimension is required total length $=96$ feet $(28800 \mathrm{~mm})$

12 storey $12 \times .05=60 \%$ of long wall dimension is required total length

$=144$ feet $(43200 \mathrm{~mm})$

Stair tower walls are sufficient in short direction up to 8 stories $(100 \mathrm{ft} / 3000 \mathrm{~mm})$

.Interior core walls required for greater heights. In long direction, use interior core walls. (120 feet/36000 mm)

\section{Solution to Exercise E 10.3}

L-shaped building needs to be divided into two rectangular areas shown by dashed lines in Figure S10.1

Reinforced masonry shear wall requirement $=40 \% \times 150$ feet $=60$ feet in each direction $(18000 \mathrm{~mm})$ Reinforced concrete shear wall requirement $=20 \% \times 150$ feet $=30$ feet in each direction $(9000 \mathrm{~mm})$

Walls around central core are sufficient: 80 feet N-S; close to 100 feet in E-W direction.

See Figure S10.1

Figure S10.1 L-shaped building

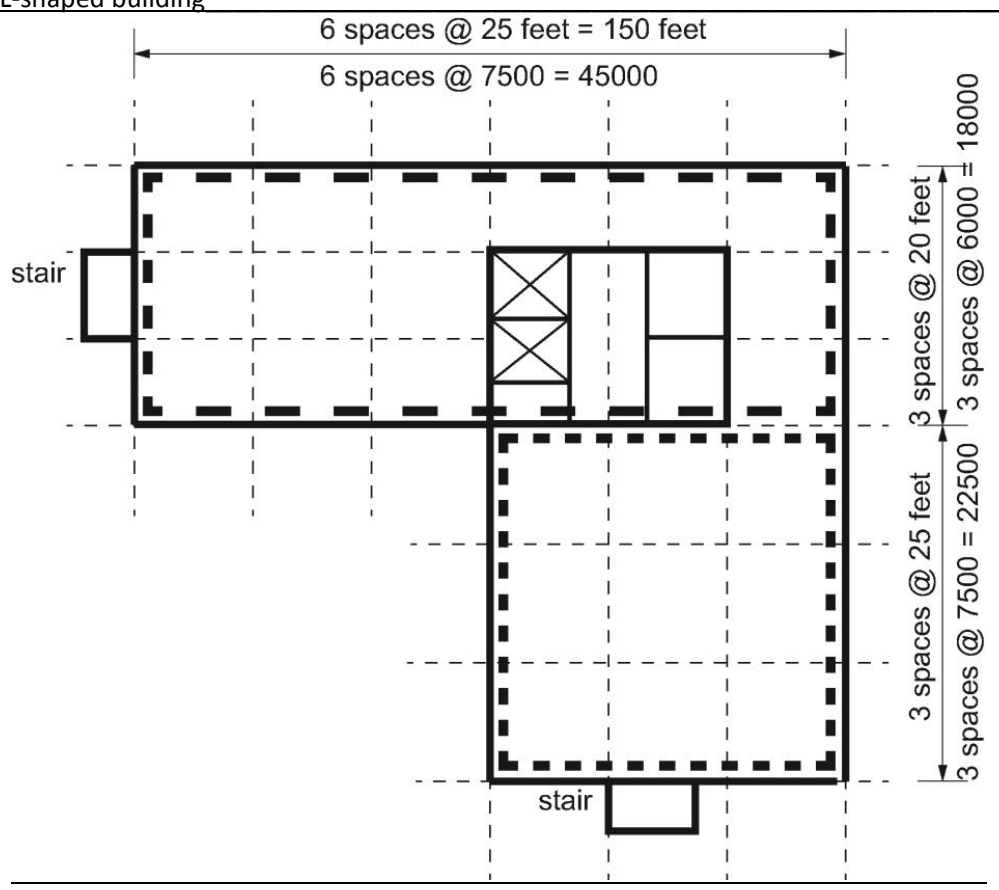

